\title{
THE STATUTORY REQUIREMENT OF A BOARD OF DIRECTORS: A CORPORATE ANACHRONISM
}

\author{
ROBERT A. KESSLER*
}

\begin{abstract}
$\gamma^{\mathrm{HE}}$ BUSINESS and affairs of a corporation shall be managed by a board of directors." So commences Section 33 of the American Bar Association's Model Business Corporation Act, and, in substantially the same words, the corresponding section of practically every corporation statute in the country. ${ }^{1}$
\end{abstract}

The sovereign has expressed itself on the subject of internal corporate management. What, however, has it actually said? Clearly the shareholders are the real owners ${ }^{2}$ of the corporation. Is the statement that the business of a corporation shall be managed by a board of directors merely a grant of permission to these shareholders to organize a committee to carry out their desires as to how the business should be run in a more efficient fashion than if they were all required individually to approve every transaction involved in the day to day operation of their corporation? Or, instead, is the statement a command that every corporation must have such a board whether it desires one or not-a kind

* Associate Professor of Law, Fordham University.

1 The provision is found in laee verba in the laws of the nine jurisdictions which have adopted the Model Act-Alaska, Colorado, The District of Columbia, North Dakota, Oregon, Texas, Virginia, Wisconsin and Iowa. Identical or substantially similar language is found in the corporation statutes of most states. See, e.g., ARK. STaT. $\$ 64-401$ (1947); CAL. CORP. CODE \$ 800; Conn. Gen. Stat. \$33-46 (1949); Del. Code Ann. tit. 8, \$141 (1953); Fla. Stat. $\S 608.09$ (1955); Idaho Code ANn. $\$ 30-139$ (1948); IND. ANN. Stat. § 25-208 (Supp. 1959); La. Rev. Stat. \& 12:34 (1950); Me. Rev. Stat. Ann. ch. 53, § 32 (1954); Mo. Ann. Code art. 23, § 52 (1957); Mass. Gen. Laws ch. 156, § 21 (1959); N.J. Rev. Stat. \$14:7-1 (1937); N.Y. Gen. CoRp. Law § 27; OHIo Rev. Code ANN. \$1701.59 (Baldwin 1958); Pa. Stat. tit. $15, \S 401$ (1958); S.D. CODE $\$ 11.0705$ (1939); TENN. CODE ANN. \$ 48-401 (1956); WASH. REV. CODE $\$ 23.01 .320$ (1958). See also LATTIN, Corporatrons 214 (1959) [hereinafter cited as LATTIN]. Only three states give any indication that a board of directors may not be a required part of corporate government. See note 76 infra.

2 The use of this term may be criticized as begging the question. Professor Dodd has suggested that the increasing powers of the management group "are easier to reconcile with an unorthodox theory that corporate managements hire capital, than with the traditional assumption that shareholders, as owners of corporate capital, hire management." Dodd, The Modern Corporation, Privale Property and Recent Federal Legislation, 54 HARv. L. REv. 917-21 (1941). Likewise, those who are wont to advocate greater shareholder rights are readily identifiable by their emphasis on the point that the shareholders are the "real owners" of the corporation. See Caplin, Proxies, Annual Meetings and Corporate Democracy: The Lawyer's Role, 37 VA. L. REv. 653, 656, 688 (1951); Emerson \& Latcham, Law and the Future: Corporation Law, 51 Nw. U.L. Rev. 196, 206 (1956). Nonetheless, this characterization of the shareholders represents the traditional legal position, and thus seems justified. Stevens, Corporations, 413-14 (1949) [hereinafter cited as STEVENS]. 
of legislatively ordained aristocracy or group of Platonic guardians, somehow more fit to rule than these shareholders, the general body of corporate citizens? ${ }^{3}$

It is difficult to say exactly what the "sovereign will" in each enacting state actually was. However, it is clear that such provisions have been interpreted by the courts of most states to evince a legislative intent that the board of directors exercise not merely a general caretaker function in behalf of the shareholders, but that it exercise a control over corporate affairs. This control is to an extent consonant only with a theory that the board represents a necessary aristocratic body, which, as the ideal form of corporate government, must be accepted by all persons who desire the privilege of limited liability.

The state, of course, has an "interest" in the manner in which corporations operate and thus in their management structure. But just as the total "interest of the state" is merely the enlightened total of the interests of its citizens, so the interest of the state in corporate structure would appropriately seem to be only the total interest of the corporation's employees, shareholders, and creditors. If these groups are well served by some form of corporate government other than the traditional shareholder-director-officer pyramid, the interest of the state is not thereby infringed. Viewed in this light, statutory provisions calling for a board of directors move from the clearly mandatory into at least a penumbra of the directory, and the concept of director status as membership in a legislatively constituted management elite dissolves into an arrogant self-delusion.

Although, as will be argued below, the legislatures enacting such statutes probably intended them to be merely concessions to customary business practices rather than required norms of corporate organization, the courts have given clear indication of their acceptance of a guardian theory of corporate organization by: (1) their strict requirements of adherence to protocol in directors' actions; (2) their refusal to make the directors responsive to business decisions of the shareholders; and (3) their refusal to grant to the shareholders a power of removal, or "recall," of directors who fail to carry out the wishes of their electorate. ${ }^{4}$

The trend toward regarding the board of directors as a kind of group of Platonic guardians whose right to rule was a legislative mandate probably be-

${ }^{3}$ As to the character of Plato's guardian, see REPUBLIC Books III and IV (Shorey transl. 1937). See also Wormser, Directors-Or Figutes of Earth?, 1 BrookLYN L. REv. 28 (1932), arguing that directors should be held to a high standard of diligence concomitant to their exalted status. The author summarizes the guardian decisions of its leading proponent, New York, with apparent approval.

4 This anti-shareholder attitude has flourished despite the fact that many of the older statutes (not, however, the Model Act and its progeny) seem to give clear recognition to the shareholders' preeminent rights by expressly subjecting directorial power to limitations in the certificate or bylaws enacted by the shareholders. See, e.g., CAL. CoRp. LAw $\$ 800$; DEx. CODE ANN. tit. 8, $\$ 141$ (1953); N.Y. GEN. CoRp. LAw $\$ 27$, conferring the power to make bylaws on the directors, but only "subject to the bylaws," if any, adopted by the members (shareholders) of the corporation. 
gan with the case of Jackson v. Hooper. ${ }^{5}$ There New Jersey's highest court refused to enforce a shareholders' agreement by which the directors were to be mere "dummies" voting in accordance with instructions from the shareholders. Intimations of the same attitude were evident even earlier in the United States Supreme Court decision in West v. Camden, ${ }^{6}$ where an agreement binding a director to vote for retaining a certain person as vice-president was held void because it "bound the defendant as to his future action as a director."

The principal exponent of the theory of directorial sanctity, however, is probably New York, which very early espoused the rule that the board of directors is no mere product of the stockholders' creation, but rather a form of state agency. In Hoyt v. Thompson's Executor, ${ }^{8}$ decided in 1859, the court rejected the theory that the directors are mere agents of the shareholders, and instead held:

[I]n corporate bodies the powers of the board of directors are, in a very important sense, original and undelegated. The stockholders do not confer, nor can they revoke those powers. They are derivative only in the sense of being received from the state in the act of incorporation. ${ }^{9}$

With one significant deviation, ${ }^{10}$ later New York cases $^{11}$ have shown the same respect for the board of directors as an inviolable institution.

Not only have agreements whereby the board will be subservient to a single shareholder been held violative of public policy, ${ }^{12}$ but also those arrangements in which a majority of the shareholders, ${ }^{13}$ even all of them, ${ }^{14}$ agree to such a deprivation of the "inherent" powers of the directorate have been held void in the New York courts.

376 N.J. Eq. 592, 75 Atl. 568 (Ct. Err. \& App. 1910).

6135 U.S. 507 (1890).

${ }^{7}$ Id. at 520.

819 N.Y. 207 (1859). The case did, however, uphold a bylaw which allowed business to be transacted by a quorum of five out of twenty-three directors, and, hence, in effect validated the "executive committee," a symbol of the rejection of the guardian theory of director status, since it represents a delegation of their powers.

${ }^{9} I d$. at 216.

${ }^{10}$ Clark v. Dodge, 269 N.Y. 410, 199 N.E. 641 (1936), which upheld an agreement between the two sole shareholders of two corporations whereby the defendant majority stockholder not only agreed to vote his stock in accordance with the agreement, but also agreed to vote as $a$ director that the plaintiff (ousted minority shareholder) should (a) continue as a director, (b) continue as general manager so long as he remained "faithful, efficient and competent," (c) receive for life one-fourth of the net income of the corporations either as salary or dividends, and (d) not have his profits affected by unreasonable salaries to other officers and agents.

${ }^{11}$ See, e.g., Manson v. Curtis, 223 N.Y. 313, 119 N.E. 559 (1918); McQuade v. Stoneham, 263 N.Y. 323, 189 N.E. 234 (1934); Benintendi v. Kenton Hotel, 294 N.Y. 112, 60 N.E.2d 829 (1945); Long Park, Inc. v. Trenton-New Brunswick Theatres Co., 297 N.Y. 174, 77 N.E. 2d 706 (1948).

12 Manson v. Curtis, supra note 11.

${ }^{13}$ McQuade v. Stoneham, 263 N.Y. 323, 189 N.E. 559 (1918).

${ }^{14}$ Long Park, Inc. v. Trenton-New Brunswick Theatres Co., 297 N.Y. 174, 77 N.E. 2d 706 (1948). 
Even attempts to limit the voting rights of the board have been interdicted as violative of the statutory ideal of a sacred board of directors. In the famous case of Benintendi v. Kenton Hotel, ${ }^{15}$ the Court of Appeals of New York decided that a bylaw providing that no action should be taken by the directors except by the unanimous vote of all of them was void because "it seems to flout the plain purpose of the Legislature."16

This "plain purpose" of the legislature was, incidentally, revealed in a statute which said nothing about greater than majority requirements for director action, but only forbade a quorum of less than one-third, and stated:

Unless otherwise provided a majority of the board at a meeting duly assembled shall be necessary to constitute a quorum for the transaction of business and the act of a majority of the directors present at such a meeting shall be the act of the board. The by-laws may fix the number of directors necessary to constitute a quorum at a number less than a majority of the board, but not less than one third of its number....17

Such brutal application of the maximum expressio unius est exclusio alterius (i.e., that since the legislature permitted bylaws allowing action by less than a majority it must thereby have intended to forbid bylaws requiring more than a majority) can really be justified only in terms of an hypothesis which assumes that the legislature has a Platonic conception of corporate management from which it would be a sin to deviate: the state in its munificence has granted the privilege of doing business in corporate form and the payment it exacts is strict compliance with the courts' understanding of what the legislative shadows in the cave indicate the sunny ideal of the corporate form to be. That this is exactly the view held by the court is made abundantly clear by its prefatory remarks:

The State, granting to individuals the privilege of limiting their individual liabilities for business debts by forming themselves into an entity separate and distinct from the persons who own it, demands in turn that the entity take a prescribed form and conduct itself, procedurally, according to fixed rules..$^{18}$

Since the shareholders' attempt through their bylaw to thus control the board was "utterly inconsistent" with the court's understanding of the legislative ideal, it had to fail. ${ }^{19}$

The more recent case of Long Park, Inc. v. Trenton-New Brunswick Theatres $\mathrm{Co}^{20}$ shows the lengths to which this deification of the boards of directors may be carried. In that case the New York Court of Appeals, at the instance of a Trenton shareholder, voided an agreement between the Trenton company

${ }^{15} 294$ N.Y. 112, 60 N.E. $2 d 829$ (1945).

16294 N.X. at 117,60 N.E. $2 d$ at 832.

${ }^{17}$ N.Y. GEN. CoRP. LAW $\$ 27$.

${ }^{18}$ Benintendi v. Kenton Hotel, 294 N.Y. at 119,60 N.E.2d at 833.

${ }^{19}$ It should be noted that the legislature soon sought to correct this misconception of its intent by enacting a provision expressly authorizing high vote and quorum requirements for both shareholders' and directors' meetings. See N.Y. GEN. CORP. LAw $\$ 9$.

20297 N.Y. 174, 77 N.E.2d 706 (1948). 
and the B. F. Keith Corporation under which the latter was to manage the theaters of the former for 19 years, on the ground that this agreement was violative of the statutory provision that "business of a corporation shall be managed by its board of directors." 21 This result was reached despite the fact that not only the board of directors, but all of Trenton's shareholders had originally approved the contract. The court said:

We are not confronted with a slight infringement or innocuous variance from the statutory norm, but rather with the deprivation of all the powers of the board insofar as the selection and supervision of the corporation's theaters, including the manner and policy of their operation, are concerned. ${ }^{22}$

Thus the board of directors is viewed as an inviolable body of Platonic guardians who are not only not subject to the will of the shareholders, but who may not even themselves abridge their inherent powers. The impervious position of the directors is further fortified by the present majority rule that they may not be removed on mere shareholder dissatisfaction, but only for some dereliction of duty. ${ }^{23}$

The New York attitude is shared at least in part by the majority of American jurisdictions. For example, Ballantine summarizes the general law on the subject of shareholder control of directors as follows: "Shareholders cannot give orders to the directors, or act for the corporation, unless by unanimous vote or agreement." ${ }^{24} \mathrm{He}$ further states that agreements which involve a surrender or "abdication by the board of its power and duty of supervision and control" are likewise "invalid," 25 adding that in the absence of a statutory authorization the shareholders may not remove directors except for cause. ${ }^{26}$

21 N.Y. GEN CORP. LAW $§ 27$.

22297 N.Y. at 179,77 N.E.2d at 709.

${ }^{23}$ See Baltantine, Corporations 433-34 (1946) [hereinafter cited as Ballaantine]; Stevens 760.

${ }^{24}$ Batrantine 121. It is to be noted that this rule is still more liberal than that laid down in Long Park, Inc. v. Trenton-New Brunswick Theatres Co., 297 N.W. 174, 77 N.E.2d 706 (1948).

${ }^{25} I d$. at 136.

${ }^{26}$ See note 23 supra. See also Berle and Means, The Modern Corporation and Private Property 138-40 (1937):

"It has been observed that under the original corporate situation there was a large amount of residual control in the shareholding group. A weakening of this control is a study by itself; only the major steps can be noted here...."

"The second major change was the disappearance of the principle that shareholders had the right to remove directors at will. This power, included in some early statutes was also apparently permitted at common law and so noted by Chancellor Kent. The statutory provisions have disappeared; the common law principle today is otherwise. Once in office directors can serve out their term without any interference by the shareholders until the next election save where the charter includes a specific power of removal-a rare circumstance in the case of all but subsidiary corporations. Directors are thus supreme during their time. Directly with this goes the principle always recognized and now considered controlling, that directors, while in office, have almost complete discretion in management; and most of the general corporation acts in terms so provide." 
There is an abundance of cases from throughout the country to support all these statements. ${ }^{27}$ The total effect is firmly to establish the board of directors as an ordained corporate priesthood - not only as a necessity for any business which intends to assume the corporate form, but as a body of corporate "guardians" whose prerequisites are ultimately inviolable. Of course, as a concomitant to this aristocratic status, directors are held to higher responsibilities, just as Platonic "guardians" would be: They are bound by fiduciary duties to the corporation, ${ }^{28}$ if not necessarily to its shareholders. ${ }^{29}$

Although the cases do not make it express, they indicate that the status of the board of directors is analogous to that of a legislative body under a "delegative" theory of democratic government. The directors have been held to be the "representatives" of the entire body of shareholders and hence not subject to the dictates of even a majority of their "constituents," the shareholders. ${ }^{30}$ Their decisions are required to be made at a board meeting, at which they may not be represented by proxy, although each director individually consents to the proposed action. ${ }^{31}$ Such a requirement can be justified only on the ground that the board of directors is a deliberative body of "the elect," analogous to the conception held by the founding fathers for the United States Senate. ${ }^{32}$

${ }^{27}$ The leading case on the shareholders' inability to give orders to the directors is Automatic Self-Cleansing Filter Syndicate v. Cuninghame [1906] $2 \mathrm{Ch}$. 34. See also Continental Securities Co. v. Belmont, 206 N.Y. 7, 99 N.E. 138 (1921); Ballantine 14; 3 Fletcher, Cyclopedia of Corporations 450-64 (1952) [hereinafter cited as Fletcher]; LatTIn 331.

As to directors' inability to abridge their own powers by delegation, see Charlestown Boot \& Shoe Co. v. Dunsmore, 60 N.H. 85 (1880); Hayes v. Canada, A. \& P. S.S. Co, 181 Fed. 289 (1st Cir. 1910); Sherman \& Ellis Inc. v. Indiana Mutual Casualty Co., 41 F.2d 588 (7th Cir. 1930); Lattin 225; Ballantine 135-36; 2 Fletcher 496-98.

As to shareholder inability to remove directors except for cause see 2 FLETCHER 149-51 Ballantine 434-35; LatTin 215-16. Cf. Ballantine's statement that "the weight of authority and reason, however, upholds an agreement among shareholders with reference to the joint management of a close corporation by its owners so that it may be conducted much like a statutory partnership. ..." BaLtantine 423.

${ }^{28}$ The proposition is so universally accepted as not to require citation of authority. See 13 Asr. JUR. Corporations $\$ 997$ (1938).

${ }^{29}$ See, e.g., the famous case of Goodwin v. Agassiz, 283 Mass. 358, 186 N.E. 659 (1933). But cf. the more recent trend in the law as exemplified in Perlman v. Feldmann, 219 F.2d 173 (2d Cir. 1955).

${ }^{30}$ Automatic Self-Cleansing Filter Syndicate Co. v. Cuninghame, [1906] 2 Ch. 34.

${ }^{31}$ See, e.g., Baldwin v. Canfield, 26 Minn. 43 (1879); Stevens 656; Ballantune 123; Latinn 219.

${ }^{22}$ See The Federalist No. 27, at 178 (Tudor ed. 1937) (Hamilton): "There is reason to expect that this branch [the Senate] will generally be composed with peculiar care and judgment; that these circumstances promise greater knowledge and more extensive information in the national councils, and that they will be less apt to be tainted by the spirit of faction, and more out of the reach of those occasional ill-humors, or temporary prejudices and propensities, which, in smaller societies, frequently contaminate the public councils, beget injustice, and oppression of a part of the community, and engender schemes which, though they gratify a momentary inclination or desire, terminate in general distress, dissatisfaction, and disgust."

From the quotation it is clear that the Senate is to be a deliberative body of select individuals chosen because of their possession of special knowledge and judgment, and exercising a 
A concept of proper corporate government under the prevailing theory is that it should be a microcosm of an ideal political government. Naturally, under such a view it is as unthinkable to abridge the powers of the board of directors; and as traitorous to advocate its abolition, as it would be to make similar attacks on the rights and existence of the Senate. Like the guardians, the directors will be superior men, secure in their positions and hence free from base pressures. Thus, they will be capable of that self-detached rational judgment necessary to the proper management of the corporation on the basis of what is objectively best for it and, ultimately, for every shareholder.

But, it is, after all, a form of corporate management which is being dealt with, and not a system of national government, convenient as the analogy may be. It may not, therefore, be a symptom of dangerous radicalism to question both the validity and wisdom of a system of corporate government the effectiveness of which is indisputable in the political realm. Two questions may properly be asked: (1) Is the guardian theory required by the history of corporation law and the present configuration of corporation statutes? (2) Should the guardian theory be rejected in favor of greater shareholder control?

\section{The Board of Directors as a Group of Platontc Guardians Is Not AN INHERENT Feature of a CORPORATION}

\section{The Common Law}

The theory that the board of directors is an inherent part of a corporation, and therefore that its rights may not be encroached upon, is ultimately traceable to the "concession theory" of corporateness. This theory holds that the right to act as a corporation is a gift bestowed by the grace of the sovereign, and like most gifts may be conditioned on a quid pro quo. If people want to enjoy the privilege of incorporation they should be willing to abide by the formalities which the statute requires. The unexpressed universal in this syllogism is that corporations are somehow special grants (concessions) by the state for which their owners owe a kind of special debt-conformity to the statutory norms, the "ideal" pattern of corporate government..33

It is, however, still a matter of dispute among legal historians whether corporations were from the beginning peculiar franchises bestowed by the sovereign, or whether the privileges of corporateness were arrogated by individuals to themselves and merely recognized by the sovereign. ${ }^{34}$ If corporations

necessary paternalistic control over the popular rashness, in short, an organ closely paralleling Plato's guardians. The opposing analogy is, of course, to consider corporate government as a kind of town meeting of the shareholders, the archetype of a democratic as opposed to an aristocratic form of government. See Caplin, Proxies, Ammeal Meetings and Corporate Democracy: The Lawyer's Role, 37 VA. L. REv. 653, 693-96 (1951).

${ }^{33}$ For a statement of the concession theory of corporations, see LATTIN 148-57. 1959).

34 See Stevens 2-3; Baker \& Cary, Cases and Materiats on Corporatrons 1 (3d ed. 
by prescription might exist, as Coke claims, ${ }^{35}$ the latter theory would appear to be correct. The distinction is important. If corporations were originally the creation of their members, rather than of the state, it would seem that their structure, including their form of management, should be a matter of choice of the individual incorporators, rather than of compliance with a preexisting state-fixed mould upon which existence could reasonably be conditioned. Clearly, later on, and perhaps from the very beginning, sovereign approval ${ }^{36}$ of some kind was necessary to valid existence; and it would seem, therefore, that historically the state can impose a set pattern of corporate structure upon those who seek the benefits of doing business under this form of organization..$^{37}$

It must be conceded that boards of directors, or "assistants"38 and "committeemen" 39 as they were originally called, have long existed as part of the structure of corporations. For example, the Bank of England, and the ill-fated South Seas Company, together with lesser companies, had boards of directors prior to the first English general incorporation statute in 1844; and even as early as 1742 these directors were held to a standard of care like that in our own day. ${ }^{40}$ Furthermore, both the English statute, and what is regarded as the first general incorporation statute in this country, that of New York, contained provisions similar to those of the Model Act, and of most present statutes, regarding the existence of the board, and its right to manage the business of the corporation. ${ }^{41}$ That the existence of a board of directors is, however, not an

35 Sutton's Hospital Case, 10 Coke 23a, 77 Eng. Rep. 960 (1613). See also Porrer, HrsTORICAI. INTRODUCTION to ENGLISH LAW AND ITs INSTITUTIONS 641 (4th ed. 1958), stating that Oxford and Cambridge Universities and the Inns of Court are examples of corporations by prescription.

${ }^{36}$ Williston argues that Blackstone was in error in saying that the voluntary association of the members was sufficient under the civil law for corporateness. Williston, The History of the Law of Business Corporations before 1800, in 3 SeIECT Essays IN ANGLO-AMERTCAN LEGAI. HrsToRY 195, $197 \mathrm{n}$.2. He does concede, however, that, although business corporations always required express governmental grant, older corporations did not. Williston says: "But, since corporate bodies were recognized as facts from the earliest dawn of history, when the rule became recognized that the authority of the supreme power of the State was necessary for their formation, a theory had to be found to support the old associations, which had not been formed in accordance with the rule. This was done both in Roman and in English law by recognizing that a corporations could come into existence by prescriptions." Id. at 205. He adds, however, that business corporations from the first required authorization by the King or Parliament.

${ }^{37}$ However, to say that there is a need for recognition by the sovereign, is not the same as saying that all corporate privileges are a gift or concession from the sovereign.

${ }^{38}$ Formoy states that this was the name whereby directors were first known. Formox, THE Historical Foundations of CoMpany Law 21 (1923) .

${ }^{39}$ See Williston, op. cit. supra note 36 , at 227.

${ }^{10}$ See Charitable Corporation v. Sutton, 2 Atk. 400, 26 Eng. Rep. 642 (1742).

${ }^{41}$ The first English general incorporation statute, that of 1844, provided for corporate management by a board of directors. What is regarded as the first American general incorporation statute, that of New York in 1811, similarly provided:

"II. And be il fusther enacled, That the stock, property and concerns of such companys shall be managed and conducted by trustees, who, except those for the first year, shall be elected at such time and place as shall be directed by the by laws of the said company...." N.Y. Sess. Laws 1811, ch. LXVII. 
inherent quality of a corporation is indicated by the change in the English statute in 1862 to omit the requirement (if such it was) of the earlier statute. That there was in fact no such requirement under the latter act was held in the case of In re Bulawayo Market \& Offices Co. Ltd. ${ }^{42}$

Further support for the argument that a board of directors is not an inherent feature of a corporation comes from the significant omission of the board not only as one of the things "of the essence of a corporation," but also from the list of corporate powers as set forth by Lord Coke in the first great English corporation decision, Sutton's Hospital Case. ${ }^{43}$ Similar evidence of the true repository of corporate management power is found in this statement:

In the absence of a provision to the contrary in the charter of a corporation or the general law, the management and control of the corporation is vested primarily in the stockholders or members collectively as constituting the corporation, and in them alone. No one else can act for or bind the corporation unless authorized by them, or by the charter or general law; and it is for them to elect or appoint the officers or agents to represent and act for the corporation, and to define their powers, unless there is some charter or statutory provision to the contrary. In other words, if there is no statute or charter provision vesting control in a board of directors or trustees, then the stockholders retain the right to manage the corporation....44

One may well ask then whether the statutory provisions that the business of a corporation shall be managed by its board of directors were not all designed to be concessions to normal business practice, as opposed to mandatory requirements for operating under the corporate form. God's blessing, "Increase and multiply," ${ }^{25}$ has often been similarly misinterpreted as a command.

42 [1907] $2 \mathrm{Ch}$. D 458, 463. The requirement was restored in 1929, but corporations incorporated under the earlier act were allowed to continue without directors if they desired. See 5 HaISBURY'S Laws OF ENGLAND 296 (Hailsham ed. 1932).

4310 Coke 23a, 29b, 77 Eng. Rep. 960, 68-69 (1613). In this case, things "of the essence of a corporation" are listed as follows:

"Now it is to be seen that things are of the essence of a corporation. 1. Lawful authority of incorporation: and that may be by (b) four means, sc. by the common law, as the King himself, \&c. by the authority of Parliament; by the King's charter (as in this case); and by prescription. The $2 \mathrm{~d}$, which is of the essence of the incorporation, are persons to be incorporated, and that in two manners, sc. persons natural, or bodies incorporate and political. 3. A name (c) by which they are incorporated; as in this case governors of the lands, etc. 4 . Of a place, for without a place no incorporation can be made; here the place is the Charter-house in the County of Middlesex. ... By words sufficient in law, but not restrained to any certain, legal, and prescript form of words." For Lord Coke's list of the corporate powers, see 10 Coke at 30b; 77 Eng. Rep. at 970.

14 5 FLETCHER 425. It is interesting to note that, even today in England and in approximately one-quarter of the American states, statutes permit election of corporate officers directly by the shareholders. BAKER AND CARY, CASEs AND MATERIALS ON CoRporations 282 (3d ed. 1959). See, e.g., Der. Code ANN. tit. 8, § 142(a) (1953); PA. Stat. tit. 15, § 406 (1958). Massachusetts is probably unique in requiring that the treasurer and "clerk" be so elected. MASS. GEN. LAwS ch. 156, $\S 22$ (1959). The existence of such power is, of course, additional evidence of legislative rejection of the "guardian theory."

${ }^{45}$ Genesis 1:28 (Douay). For just such a misinterpretation of the biblical passage, see Benjamin Franklin, "The Speech of Polly Baker," reprinted in "The Franklin Papers," Life Magazine, Oct. 5, 1959, 105, at p. 120. 
Even if it be conceded that the existence of the board of directors is necessary under the customary statutory provisions which place the business and management of the corporation in the hands of its board of directors, does it follow that its powers are absolute and unimpeachable by the shareholders; or are the shareholders at liberty to "take over" for themselves, and to deprive the board of the powers normally conferred upon it? The answer to this question is, at least in part, aided by the answer given by the cases to the question of the directors' status. The same opinion, Charitable Corporations v. Sutton, which held that directors are liable for misfeasance in office also contained the statement:

I take the employment of a director to be of a mixed nature: it partakes of the nature of a publick [sic] office, as it arises from the charter of the crown.

But it cannot be said to be an employment affecting the public government; and for this reason none of the directors of the great companies, the Bank, South-sea $\& c$., are required to qualify themselves by taking the sacrament.

Therefore committee-men are most properly agents to those whom [sic] employ them in this trust, and who empower them to direct and superintend the affairs of the corporation. ${ }^{46}$

If the directors are agents they are subject to the commands of their principals, merely enjoying the powers granted to them, and subject to control or even removal at the pleasure of their principals for failure to carry out their wishes; and, therefore, they do not enjoy the status of Platonic guardians whose powers are inviolable, or of Senators whose functions are unquestionable (except at election time).

The common law rule denied the guardian or Senator status, and made the director a mere agent. The view taken in Charitable Corporations v. Sutton is supported by Holdsworth, who states that the majority of stockholders of a corporation may exercise any of the powers of a corporation, despite directions to the contrary in their foundation statutes. ${ }^{47}$ To the same effect is the holding of the United States Supreme Court in Union Pacific Ry. Co. v. Chicago \& $R y . C o{ }^{48}$ That case upheld the validity of a contract entered into by an executive committee and approved by the majority of the shareholders, despite the fact that the board of directors never formally acted on the agreement. The Court stated:

${ }^{46}$ Charitable Corporation v. Sutton, [1742] 2 Atk. 400, 405, 26 Eng. Rep. 642, 644.

179 Holdsworth, History of ENGLise LAw, 54 (1922). See also Holdsworth, English Corporation Law in the 16th and 17th Centuries, 31 Yale L.J. 382, 391 (1922):

"It was settled before the sixteenth century that any of the powers belonging to a corporation could be exercised by a majority of the corporators-a principle which an Act of 1541-2 enforced on corporations notwithstanding any directions to the contrary contained in their foundation statutes." This initial common law rule is to be contrasted with contemporary misinterpretations of Automatic Self-Cleansing Filter Syndicate v. Cuninghame [1906] 2 Ch. D. 34 .

18163 U.S. 564 (1895). See also note 44 supra. 
When by the charter of a corporation its powers are vested in its stockholders, and this was the common law rule when the charter was silent, the ultimate determination of the management of the corporate affairs rests with its stockholders, and the charter of the Pacific Company did not commit the exclusive control to the board of directors..$^{49}$

The Court further held that the general rule of shareholder power to act in supercession of the board of directors applied, despite the argument that the statute under which the railroad was organized provided for appointment of five of the twenty directors by the President of the United States, and that the contract had to be approved by at least one of these "government directors." The Court added:

We regard the position as wholly untenable that this provision for government dixectors took the corporation out of the general rule that except in cases where the charter imposes a limitation the stockholders are the proper parties to take final action in the management of corporate affairs. ${ }^{50}$

Thus it seems clear that the common law rule was that the power ultimately to manage the corporation belonged to the shareholders; the directors were mere agents of the shareholders, so far as their powers of management were concerned; ${ }^{51}$ and, as the mere agents of the shareholders their powers to act for the corporation were abridgable at the will of the real owners of the corporation.

Further evidence of the real nature of the directors as mere servants, subject to the bidding of the corporate shareholders, is provided by the original concept of a corporation as a common property of the shareholders. ${ }^{52}$ Even more con-

${ }^{19} I d$. at 596.

${ }^{50} \mathrm{Id}$. at 600 . Further evidence of the fact that the ultimate corporate power at common law belonged to the shareholders, who could if they chose displace the board of directors, in the fact that originally what is today regarded as one of the prime prerequisites of directors-the power of electing the corporate officers- "like every other power," inhered in the body of shareholders at large. See 2 Fletcher 568; Angelt \& Ames, Private Corporations 107, 300 (5th ed. 1859). Although the right to delegate this and other powers to a "select body," e.g., the directors, was recognized as a matter of business convenience, some courts have even refused to allow the shareholders to give away this right which really belonged to them. $I d$. at 108, 109 n.1.

An early corporation textbook also clearly indicates that the board of directors was generally considered as merely one of other possible devices for corporate management the choice among which would normally lie with the shareholders, that where the shareholders chose to have directors they were generally regarded as mere agents of the shareholders, and that, as a result, what are today considered the inherent rights of the board, were not only limitable by the shareholders, but even where powers were expressly conferred they would be strictly construed by the courts. Id. at $107,300-02,343$.

A good indication of the truly servile status of directors at the common law is given in the statement: "Boards of directors, managers, \&c., are agents of the corporation, only so far as authorized directly or impliedly by the charter; . . Id . at 304 .

51 This, of course, does not preclude holding them to the fiduciary standard of trustees. See notes 28 supra, and 81 infra. It is interesting to note that, if corporate managers other than directors are allowed, the fiduciary standard may even rise in certain instances. See BarrarTINE 165.

52 Williston, op. cit. supra note 36 , at 217. 
clusive proof is the common law rule that directors could be removed at the will of the shareholders without cause. As Stevens states the rule: "Shareholders have inherent power to remove any director, officer, or agent appointed by vote of the shareholders." ${ }^{\text {53 }}$ And such right is still recognized even in New York, a state not noted for the liberality of its corporate case law, if the certificate of incorporation or the bylaws so provide. ${ }^{54}$ If the shareholders have the right to remove directors at will, it is clear that the directors are not a species of corporate guardians, but rather are proxies for the shareholders-creatures of convenience, not of necessity. As such, their rights may be abridged at the will of the shareholders, and hence are not a part of any statutory scheme imposed on incorporators for the privilege of limited liability. It would seem to follow that the body of shareholders should be able to give orders to the board whenever it wishes, as principals may do with their agents. Yet Ballantine tells us that the rule is otherwise:

Shareholders cannot give orders to the directors or act for the corporation, unless by unaminous vote or agreement.

It is generally held that if the shareholders attempt by a resolution passed by a majority of their number to order the directors to make a contract, as for the sale of the assets of the company, they cannot thus override the directors' discretion and power of management. ${ }^{55}$

From this supposed rule Ballantine draws a conclusion on the status of directors opposite to that which has been suggested: "The directors are not servants to obey directions and orders given them by majority shareholders." ing case on the subject, upon which Ballantine relies, is Automatic Self-Cleaning Filter Syndicate v. Cuninghame. This is the decision that is most often cited for Ballantine's proposition and is the progenitor of the rule that the shareholders may not interfere with the discretion confided to the directors. This case, however, does not really stand for the broad proposition for which it is cited, but actually only for the rule that a mere majority of the shareholders may not give orders to the directors where the articles provide that the directors shall have "the full powers which the company has" subject only to law and a resolution passed by three-quarters' vote of the shareholders. ${ }^{58}$

Clearly on this ground the case is correctly decided and is quite consistent with a theory that the shareholders have the ultimate power in determining the management of the corporation. Clearly, if by the charter, their creation,

\footnotetext{
${ }^{63}$ Stevens, 706. Compare the more recent law, which Ballantine states to be the rule today. Note 23 supra.

54 See Stevens 762-63.

${ }^{55}$ Batlantine 121-22.

${ }^{66} \mathrm{Id}$. at 120. 34.

${ }^{77}$ Miscited, however, by Ballantine as "Automobile" Self-Cleansing etc., [1906] 2 Ch. D.

${ }^{88}$ Summary of charter by Collins M.R. 2 Ch. D. at 42 .
} 
shareholders wish to set high vote requirements for corporate action, they should have the right to do so. This is exactly what is denied them by the guardian theory enunciated in the Benintendi case..$^{59}$ One may wholeheartedly agree with the statement of Collins, M. R. in the Automatic case: "If the mandate of the directors is to be altered, it can only be under the machinery of the memorandum and articles themselves, I do not think I need say more." 60

The corporation belongs to the shareholders. At the common law, the directors were merely their agents, subject to their control, as expressed in the corporate charter, and to their decisions made in accordance with this corporate structure. $^{.1}$

\section{Evasions Permilted}

Even the modern statutes which are (at least in the eyes of interpreting courts) devoted to the guardian theory allow for effective circumvention of the required inviolability. For example, in New York bylaws passed by the directors are subordinate to bylaws passed by the shareholders. ${ }^{62}$ This recognizes that the ultimate management of the corporation is in the hands of the shareholders. That state also has enforced a bylaw requiring the president of the corporation to call a special shareholders' meeting on demand of a certain percentage of shareholders, even though the obvious purpose of this meeting was to overrule the board of directors by replacing the old president who had been fired by the board. ${ }^{63}$

Similarly, Delaware has upheld the shareholders' right to control the board by "packing" it; that is, by creating new directorships sufficient in number to

59294 N.Y. 112, 60 N.E.2d 829 (1945). See note 11 supra.

$602 \mathrm{Ch}$. Div. at 43.

${ }^{61} \mathrm{It}$ is interesting to note on the question of the board of directors as an inherent part of a corporation that the Charter of the Presbyterian Minister's Fund in Pennsylvania in 1759, a product of a period of severely restrictive thinking on corporate powers, created no board of directors and, as a later court interpreted it, "apparently contemplated a management by the corporators themselves." Commonwealth v. Acker, $308 \mathrm{~Pa} .29,162$ Atl. 159 (1932). See also Ballard, Arrangements For Participation In Corporate Management under the Pennsylvania Business Corporation Law, 25 TEMP. L.Q. 131, 131-33 (1951).

Another indication of the true status of directors as mirrors of the shareholders' will as opposed to a special class of state officials is given by the requirement in many states that they themselves be shareholders, thus guaranteeing their representative, as opposed to delegative, function. See Stevens 650.

62 N.Y. GEN. CORP. LAW $\$ 27$ provides: "Subject to the by-laws, if any, adopted by the members of the corporation, the board may make necessary by-laws. Section 14 (5) of the same act provides: "By-laws duly adopted at a meeting of the members of the corporation shall control the action of the directors except as therein otherwise provided."

${ }^{63}$ Matter of Auer v. Dressel, 306 N.Y. 427, 118 N.E.2d 509, (1954). In that case mandamus was upheld to compel the new president to call a shareholder meeting which the bylaws required him to do whenever, as was the case, "requested in writing to do so, by stockholders owning a majority of the capital stock entitled to vote at such meeting" despite the fact that the "obvious purpose" of the meeting was to reinstate the old president and to remove the directors who had fired him. 
outweight the incumbent board, and by filling the vacancies with directors who who more willing to carry out the shareholders' will..$^{64}$

These decisions are clearly correct, for they place control of the corporation where it was at the common law-in the shareholders. But useful as legal fictions have been in the past, ${ }^{65}$ there would seem to be no good reason for resorting to them at such a late date in place of a self-consistent theory of the nature of a corporation which would recognize that the shareholders have the right to run the corporation as they choose, despite the institution of the board of directors.

Another indication of weakness in the concept of directorial inviolability is the "executive committee," allowed in most jurisdictions today. ${ }^{66}$ Although its powers cannot under the prevailing view encompass a complete surrender by the

64 Campbell v. Loew's Incorporated, 134 A.2d 852 (Del. Ch. 1957).

65 See Mande, ANcient Law 26-47 (10th ed. 1906); and, as to the use of fictions to extend the jurisdiction of the Courts of King's bench and Exchequer in England, see 1 Hordswortr, History OF ENGLISH LAW 220-22, 231 (1922).

${ }^{66}$ See, e.g., ABA-ALI MoD. Bus. Corp. Act $\$ 38$ (1953).

In addition to the Model Act states, see Ala. Code tit. 10, $\$ 25$ (Supp. 1955); Ark. Stat. \$ 64-402 (1947); Cax. CoRp. Code \$ 822; ConN. Gen. Stat. \$33-46 (1958); Det. Code AnN. tit. 8, §141(c) (1953); Fla. Stat. \$608.09(2) (1955); IDAHo CODE ANN. § 30-139(e) (1948); Ill. Rev. Stat. ch. 32, § 38 (1957); Ind. AnN. Stat. § 25-208 (1955); Kan. GeN. Stat. ANN. \$17-3101 (1949); Kx. Rev. Stat. \$ 271.345(4) (d) (1955); LA. Rev. Stat. ANN. \$12:34(7) (1950); Me. Rev. Stat. ANn. ch. 53, §32 (1954); Md. ANn. Code. art. 23, $\$ 59$ (1957); Mass. Gen. Laws ch. 156, §§13, 26 (1954); MIcH. CoMr. Iaws. § 21.13 (Supp. 1959); Minnv. Stat. \$301.28 (1953); Mo. Rev. Stat. 351.330 (1949); Neb. REv. Stat. \$21-114 (1943); Nev. Rev. Stat. \$ 78.125 (1949); N.J. Rev. Stat. § 14:7-4 (1937); N.M. Stat. ANN. § 51-2-14 (1953); N.C. Gen. Stat. 55-31 (1960); Ohio Rev. Code AnN. \$1701.63 (Baldwin 1958); OkLa. Stat. tit. 18, §1.36 (1951); PA. SraT. tit. 15, §402(6) (1958); S.D. CoDe §11.0707 (1939); TENN. Code AnN. \$48-406 (1957); Vt. Stat. AnN. tit. 11, §1101 (1958); Wash. Rev. Code $\S 23.36 .030(5)$ (1958); W. VA. Code ANN. $\$ 3028$ (1955).

Of course widespread legislative sanctioning of such committees is a direct rebuff to the guardian theory, since under this theory any delegation of board powers is suspect, and too great a surrender is void. See BallaNTrNe, 136.

Although some of these statutes place restrictions on the powers which may be delegated, many, like the Delaware and New Jersey statutes, and those following closely the Model Act presumably allow the board to delegate all of its ordinary management functions to such executive committees.

Although most states which expressly authorize executive committees require that they be composed of at least two members of the board, some do not fix any limits on the number necessary to constitute the committee. Among these are Connecticut, Maine, New Jersey, New Mexico, and Nevada. In those states in which no limit on the number of persons who shall compose the executive committee is provided, presumably all management functions could be delegated to a single person, and thus, effective abdication of the board's management functions-anathema to the holders of the guardian theory-can be achieved. New York, too, by case decision, and at an early date, recognized the right of a corporation to have an executive committee. Sheridan Electric Light Co. v. Chatham Nat. Bank, 127 N.Y. 517, 28 N.E. 467 (1891). It now does so by statute, but in a roundabout fashion: N.Y. GEN. CoRP. LAW $\$ 31$ allows "the board of directors or any committee thereof" to waive notice of any meeting. It could be argued, therefore, that even guardian-minded New York, because of the absence of limitations, would recognize a delegation of management to a one-man committee (at least for periods when the board was not in session), a clear cession of the supposedly inviolable powers of the board. 
board of its control over the management of the corporation, ${ }^{67}$ many statutes and decisions allow an executive committee to exercise what would normally be the powers of the board over the "ordinary business of the corporation." power to delegate, albeit limited, is yet another recognition that there is nothing inherently sacred in the board of directors and its management function.

Decisions in states not so fettered by the guardian theory, ${ }^{69}$ and statutory amendments by the principal exponent of that theory, New York, have, in effect, allowed the "sterilization"70 of the board which the New York courts' guardian interpretation of the board of directors section held violative of public policy. For example, New Jersey by decision relying on "the general law," "71 and New York by statutory amendment, ${ }^{72}$ now allow a corporation to require unanimity of the directors before taking corporate action. With proper draftsmanship, such rules can guarantee that a corporation may be run as a partnership of the shareholders. ${ }^{73}$ But whatever the ultimate effect of manipulating

${ }^{67}$ See Hayes v. Canada, A. \& P. S.S. Co., 181 Fed. 289 (1st Cir. 1910); Ballantrne 135. The Illinois statute presents an example of the most stringent express statutory limitations on the powers of the executive committee. IrI. REv. STax. ch. 32, §38 (1957). Few other statutes are so explicit. Massachusetts, for example, limits the delegation to "the management of the current and ordinary business of the corporation." MASS. GEN. LAws ch. 156, § 26 (1959).

${ }^{68}$ Mass. GeN. Laws ch. 156, $\$ 26$ (1959). The same right of delegation is given by all of the statutes listed in note 66 supra.

${ }^{69}$ See, e.g., note 71 infra.

${ }^{70}$ The picturesque expression used by the New York Court of Appeals in Manson v. Curtis, 223 N.Y. 313, 119 N.E. 559 (1918), to describe the forbidden effect of a contract whereby the defendant agreed to sell the plaintiff enough shares to enable him to possess fifty per cent voting control, and agreed that the president and board of directors were not to interfere for one year with the plaintiff's management of the business.

${ }^{71}$ Katcher v. Ohsman, 26 N.J. Super. 28,97 A.2d 180 (Ch. 1953) enjoined a directors' meeting the purpose of which was to oust the plaintiff from his position as an officer and director. Plaintiff and the two defendant directors, who each owned one-third of the stock of the corporation, constituted its board of directors. Not only did the court hold that a bylaw requiring "that no binding action could be taken either by the stockholders or directors unless 90 per cent in stock interest voted in favor of such action" would be valid, but enforced that requirement for unanimity despite the fact that there was no such bylaw with regard to directorial action, on the ground that the defendants had represented to the plaintiff that such a bylaw did exist. The court said, in clear rejection of the guardian theory: "I know of no valid reason why majority stockholders are not at liberty to establish for themselves a voting rule or formula which will protect the holder of a single share against the action of all the other shareholders becoming binding or controlling upon him."

This sensible and legally justifiable attitude of a New Jersey trial court is to be contrasted with the unfortunate conceptualism of the highest court of the nation's second most important corporation state, New York, in the cases cited in note 11 supra.

${ }^{72}$ See N.Y. STock CoRP. LAw $\$ 9$. New York is followed in this regard by the ABA-ALI MOD. BUS. CORP. ACT $\$ 37$ (1953) and a number of other jurisdictions. See O'Neal Crose Corporations 201-02 (1958). But note that the permission is not universal. Id. at 202-04.

${ }^{73}$ See, e.g. the UNLForm PARTNERShIP ACT $\$ 18$. Here a "default" law (a law for those who do not choose to "opt out") is provided with regard to partnership management and entry of new participants in the venture. But such "default" provisions are made subject to alteration 
legal technicalities, these rules are certainly another indication that the board of directors' prerogatives are not above alteration, that an inviolable board of directors is not an inherent part of a corporation. The New York amendment was expressly designed to overrule the holding of the Benintendi case. ${ }^{74}$ It can certainly be argued that it was also designed to strike down the guardian theory on which that decision relied..$^{75}$

There are, of course, many other perfectly legal ways in which the powers of

by agreement of the partners. In short, a contrachcal basis for organization, management, and entry into the business enterprise is recognized by the Uniform Partnership Law.

Solving also the problem of action by less than all of the participants or a select committee formally approving, Section 9 of the Uniform Partnership Act likewise provides for binding action by one participant in behalf of all. It is interesting to note that all of these provisions, with the word "shareholder" substituted for "partner" would adequately apply to the needs of the really "close" corporation.

The archetype of the "close" corporation desires just such freedom to "master its own fate" as is given by this partnership statute: Through acceptance of appropriate default law provisions (basically attuned to its own needs), or, through modification of them, and alteration to suit its own peculiar requirements by a contract entered into by the limited group who constitute the owners of the enterprise.

With regard to the agency powers of the participants, the Uniform Parntership Act, in effect, enacts the corporate "indoor management" rule of certain English cases that one who deals with a corporate officer in ignorance of the actual extent of his authority is entitled to assume that he possesses requisite authority from the board or shareholders to act in any ordinary transaction. See Louisville, N. A. \& C. Ry. Co. v. Louisville Trust Co., 174 U.S. 552 (1899); STEvens 773-74. The wise caveat is added that certain extraordinary transactions (such as those which might be restricted to shareholder approval) may not be assumed to be within the competence of any particular agent (or group of agents).

In general, normal agency rules apply to all corporate agents. See Joseph Greenspon's Sons v. Pecos Valley Gas Co., 34 Del. 567, 156 Atl. 350 (Super. Ct. 1931); Larmin 227-34. This facet of the corporation as opposed to the partnership imposes no great disadvantage to the choice of the former over the latter. Certainly express grants of power may achieve the same result in both forms of enterprise.

Control of new entry into the enterprise may be achieved almost as well where the corporate form is used as with a partnership through restrictions on the transferability of shares. These are usually recognized where they do not amount to an absolute prohibition on transfer. See Lawson v. Household Finance Corporation, 17 Del. Ch. 343, 152 Atl. 723 (Sup. Ct. 1930); Allen v. Biltmore Tissue Corp., 2 N.Y. 2d 534, 161 N.Y.S. 2d 418, 141 N.E.2d 812 (1957); Palmer v. Chamberlin, 191 F.2d 532 (5th Cir. 1951); Lewis v. Hood \& Sons Inc., 331 Mass. 670. 121 N.E.2d 850 (1954); LatTin 339; BaLlanTine 775-80; Stevens 598-605.

Section 18 of Uniform Partnership Law through its exception, "subject to any agreement between them (i.e., the partners)," allows restrictions on the majority power of the partners, and on the "equal management rights" of each individual partner. Such statutes as Section 9 of the New York Statute allow similar limits on the individual powers of corporate managers. Thus, under both the partnership form and in a corporation desiring to take advantage of the provisions of the New York statute, unanimity may be required for all management decisions. Thereby, a modern corporation may, albeit with more complex paper-work, operate as a partnership with the aid of a combination of previous decisional law and such permitted "veto" powers for management action.

1 Note 11 supra.

${ }^{75}$ Recommendation of the New York Law Revision Commission, Legislative Document No. 65 at p. 386 (1948): "It was the unanimous opinion of those present at the Conference that the rule of the Benintendi case should be changed by statute.... The Commission agrees with these conclusions." 
the board of directors may be circumscribed. For example, the shareholders of a small corporation may preserve as directors the same proportional control relative to shareholdings which they have as shareholders. This effectively merges the two functions by the utilization of statutory provisions allowing freedom of choice in the number of directors which the corporation may have, ${ }^{76}$ and of those permitting classification of directors and shares. ${ }^{77}$

${ }^{76}$ Of the 50 states in the Union, all but 3 appear to make the board of directors mandatory, although a few allow some variation in the title by which the directors are known. See, e.g., NEv. REv. STAT. §78.035 (1958) (refers to "directors or trustees"); S.C. CoDE § 12-52 (1952) (speaks of "directors, trustees or managers"). The three states which do not expressly command a board of directors are: Arizona, Iowa (under the "old" statute which still continues in force for corporations electing it, although the Model Act has recently been adopted), and Mississippi. See p. 725 infra. Of the states which make the board of directors mandatory, all but one (South Carolina) prescribe a minimum number of directors necessary to constitute the board, and all fix this number at 3 . This number may be explained on either of two grounds: a) That this is the minimum number necessary to provide for a rule by a majority, and for this reason is felt desirable (although with dubious logic, since no one feels it necessary to have 3 presidents whether for a corporation or the country and, unlike the nation, with a relatively small group to be represented, as in the average corporation, no intermediary legislative body is necessary); or $b$ ) That this is at anchronistic survival of mystic notions associated with the number three. As to b) it is interesting to note that Justinian's Digest 50,16,85, likewise recognizes the number "3" as important to corporations but gives no better explanation for its significance. The Digest section is translated by Sherman, Epitome of Roman Law (1937) to read: "Neratius Priscus holds that three members make a corporation [collegium] which opinion should be followed." Neratius Priscus, an eminent jurist, lived during the reign of the Emperor Trajan [98-118 A.D.]. This unenlightening source may well be the origin of both the three-man incorporator and three man minimum board requirements characteristic of our law. Neither reason seems sufficiently cogent to justify continuance of the requirement. Of the states which require a board, only four set any maximum limits on the number which may compose the board. These are Missouri (21), Mo. Rev. STAT. $\$ 351.315$ (1949); Montana (13), MonT. Rev. Codes ANN. \$15-108 (1949); South Carolina (17), S.C. CODE §12-52 (1952); and Utah (25), UTAH CODE ANN. \$16-2-5 (8) (1953).

There is, therefore, no effective bar, except for the smallest corporation (i.e. those with under 3 shareholders), to a corporation's having a number of directors equal to its number of shareholders. Manifestly where share holdings are equal and either cumulative voting or an enforceable shareholders' voting agreement exists (such "pooling" agreements are usually legal一see Batlantine 421; LATTIN 317; SteVENS 665) it is, therefore, possible to have the board of directors exactly mirror the group of shareholders, and thus effectively dispense with the board as a separate governing unit.

77 Ordinarily the term "classification of directors" refers to a permissible staggering of terms of office (e.g., one director serves for 1 year, another for 2, etc.). However, directors may also be "classified" by the classes of stock entitled to elect them. (See, e.g., the express authorization for such classification in this latter sense in CoNN. GEN. STAT. § 33-46 (1949), and MrNN. Stat. $\S 301.28$ (1953). O'Neal states: "Most of the corporation statutes seem to authorize this kind of arrangement." i.e., classification according to the class of shareholders who may elect individual directors. O'NEAI, Ctose CoRporations $106 \mathrm{n} .64$ (1958). Under such a classification arrangement it is likewise possible to have the board of directors exactly mirror the shareholder power distribution, or, if desired, confer effective control on any one or more shareholders to run the corporation, thus again effectively emasculating the board of directors as an independent corporate government. For example, to have effective shareholder control of the corporation in a corporation of 7 shareholders, each having an equal financial stake in the corporation, a board of seven directors may be established, one director to be elected by each class of the stock (each class being equal in every way except for voting rights). Each shareholder is then given a different class of stock: share- 
Manifestly, the drafting problem is a complex one; but the important thing to note is that the shareholders may, if they choose, effectively circumvent statutes which have been interpreted to require that the business of every corporation be managed by a body separate from its shareholders, in which voting rights are not proportional to ownership interest. ${ }^{78}$ The legality of such efective sterilization of the board as a part of corporate government offers further disproof of the notion that a board of directors is a sacrosanct body of guardians whose prerogatives are inviolable under the legislative plan. It raises the question of why one is not permitted to do directly what he may accomplish by indirection.

A sensible legal system does not rely on fictions unless it must do so. Although the law may develop under the pretense that it is unchanging through the use of legal fictions, there comes a time when it is necessary to discard fiction and accept reality. Perhaps now is the time to admit the truth that the board of directors as a group of Platonic guardians is no longer, if it ever was, a necessary part of the structure of a corporation. If the real owners, the shareholders, desire to dispense with it, it should be up to them to choose other agents, or, if they so desire, to retain the entire corporate management themselves. Originally they had this power. Why not now?

In this connection it is interesting to note that originally shareholders were not given a vote proportional to their ownership, but were instead treated as our boards of directors are today: one vote per person in determining the corporate management regardless of the number of shares of stock held. When methods of achieving representation proportional to actual shareholding were developed, the law recognized the modern rule of shareholder vote in proportion to shareholdings, rather than on an individual basis. ${ }^{79} \mathrm{Such}$ wisdom in deal-

holder A, holds class A stock and as such a holder is entitled to elect 1 director; shareholder $B$ elects a class B director, etc. Thus through a perfectly legal technicality the stockholders run the corporation under the name of "directors" just as they would as shareholders; and note that no "freeze-out" of any shareholder is possible, since if, for example, shareholder A is somehow removed as a director, he may always, in his capacity as a shareholder, reelect himself (unless he is so negligent as to approve bylaws allowing the directors to fill board vacancies).

Where, of course, it is desired to confer effective control of the management on one individual, this may be done by granting the right to his class of stock to elect a controlling number of directors. For example, in a three director corporation, he (i.e. his class of stock) might be given the right to elect two directors, while the remaining shareholders, possessing another class of stock, might be given the combined right to elect only one director. Thus again, the inviolable board of directors may be completely undermined where lawyers are clever enough to draft the papers properly.

${ }^{78}$ Each director, or course, has one vote whether he has been elected by a majority, or, as is possible under cumulative voting, a minority shareholder. Likewise, this director has his one vote on the board whether he himself owns a thousand shares or only one (or in many states none).

79 Williston, op. cit. supra note 36, 224-26. The circumvention device was, of course, a temporary transfer of shares to dummies who would vote as the real owners directed. The custom was known as "splitting stock." 
ing with the problem of the board of directors seems desirable today. With widespread and legally tolerated circumvention ${ }^{80}$ of the requirement of an active board of directors, it is time to give the necessary recognition to the realities of corporate operation. It is clear that the board of directors was not originally conceived as an inviolable group of Platonic guardians, nor is it so in modern legal practice. The board's true status should be recognized, and its proper rulers given their right to dispense with it if they so desire, or use it in any way they choose, if they find its retention a desirable means to exercise their sovereign power over the corporation.

\section{The Desirability of Giving Shareholders the Option To Regulate OR ABOLISH THE BOARD OF DIRECTORS}

It has been argued above that there is nothing sacred about the board of directors under a proper interpretation of the law; and that, therefore, there would be no fundamental inconsistency with past law in allowing corporate shareholders to restrict the powers of the board, or even to determine that they alone should exercise those rights in substitution for such a board. This theory, which finds support in the law, is that the powers of the directors come by delegation from the shareholders, rather than from the state. If the directors are mere agents of the shareholders so far as their authority is concerned, ${ }^{81}$ then it should follow that their powers are limitable by the shareholders, to the extent that the latter choose, and, further, that they are themselves subject to removal at the will of their principals for failure to carry out the shareholders' wishes.

It has been noted above that either originally or by taking advantage of permissible "loopholes" in present corporation statutes both of these ends are attainable. These results are consistent with the theory suggested. They effectively disprove the guardian theory of the nature of the board of directors. They do not of course prove the opposite theory of the dispensability of the board as a feature of corporate government. Under prevailing interpretations of statutory provisions establishing the board of directors, therefore, legislative amendment will probably be necessary to rectify judicial misinterpretation. ${ }^{82}$

${ }^{80} \mathrm{It}$ is interesting to note that even the holding in Long Park Inc. v. Trenton-New Brunswick Theaters Co., 297 N.Y. 174, 77 N.E.2d 706 (1948), may be circumvented by a leasing of the theaters to the corporation to which it is desired to delegate the full management. Schneider v. Greater M. \& S. Circuit, Inc., 144 Misc. 534, 259 N.Y.S. 319 (1932) upheld such a lease arrangement, although it was to run for 40 years. See LATTiN 226.

81 There is, of course, no inconsistency in holding the directors, or any other agents substituted for them, to a fiduciary standard of trustees so far as duties to the corporation and its shareholders are concerned, despite a recognition of the limited origin of their rights. See, e.g., Zahn v. Transamerica Corp., 162 F.2d 36 (3d Cir. 1947); Lebold v. Inland S.S. Co., 82 F.2d 351 (7th Cir. 1936); and Perlman v. Feldmann, 219 F.2d 173 (2d Cir. 1955) recognizing fiduciary duties even on the part of shareholders.

22 The suggestion made by Caplin that recognition of shareholder rights in corporate management through voluntary concessions by the board of directors, under the leadership of corporation lawyers, is, of course, appropriate only to the largest public issue corporations, and even this seems an overly sanguine hope. Proxies, Anmual Meetings and Corporate Democracy: The Lawyer's Role, 37 VA. L. REv. 653, 686-97 (1951). 
To inspire such legislative action, it is necessary to show not only that such action is not antagonistic to basic corporate theory but also that it is positively a desirable in order to accommodate current business needs of those corporations which desire to take advantage of the privilege.

Modern corporate theory distinguishes the "public issue" corporation, whose securities are traded on recognized public securities markets, from the so-called "close coporation," the most adequate definition of which appears to be all other corporations, i.e. corporations whose shares are not so traded. ${ }^{83}$ Typically, of course, "public issue" corporations are "big" in both assets and operations, while "close" corporations are "small" in both of these attributes and typically also have an identity of ownership and management personnel. Manifestly, how ever, there may be infinite degrees of variation between these two poles. This, as will be seen, is a cogent reason for allowing corporations themselves to elect their preferred system of corporate government, instead of having any particular system imposed upon them.

In the typical public issue corporation the number of shareholders is large. It is obvious that shareholder rule over the everyday affairs of the corporation would from a practical viewpoint be impossible, whether or not the ideal form of business organization required a more centralized form of management. For the real public issue corporation, the board of directors is like Voltaire's God: if it did not already exist the public issue corporation would have to create it.

It is with regard to such corporations that the guardian theory is most persuasive. As was stated by Mr. Ray Garrett, Chairman of the Committee which drafted the Model Act:

A publicly-held corporation is a means of conducting a large and usually complex business enterprise. Shareholders, creditors, employees, customers, suppliers, and the public generally are all concerned that such enterprises be managed efficiently. While shareholders are unquestionably entitled to the means of protecting their interests, the phrase "corporate democracy" must not be taken literally to the point of upsetting the fundamental separation of powers between the shareholders and directors. The successful management of large corporations rests largely upon this separation. ${ }^{84}$

Speaking specifically of the directors, he adds:

The truth of the matter is that directors and officers of large corporations have become professionals. Directors are selected chiefly because of their business stature and position in the industrial community, Integrity, ability and profitable association, not share ownership, are the criteria. Well-known executives, industrialists, bankers, lawyers, accountants, together with top management personnel, are chosen as directors to provide the multitude of shareholders with the integrity and business acumen essential to corporate success. This is the common practice. Directors are selected from among the professional "managerial-class," to the extent that there is such a thing,

${ }^{83}$ O'NeAr, op. cit. supra note 77, at 5; N.C. GEN. StaT. \$ 55-73(b) (1960).

81 Garrett, Altitudes on Corporate Democracy-A Critical Analysis, 51 Nw. U.L. REv. 310, 311 (1956). 
and not from the owners of the corporation. This is true even though a stockholder who owns or controls a substantial block of stock can usually obtain representation on the board. And one wonders how it could be otherwise. The director's task is to supervise management as well as, perhaps, to benefit the corporation by his association. There is nothing about share ownership that in itself qualifies a person for such a position. It is also true, no doubt, that the increase in "professional" as opposed to "owner" directors has caused increasing emphasis to be placed upon the director's fiduciary duty which replaces, in a sense, the motivation of substantial proprietary interest. This is undoubtedly desirable, and, indeed, essential. ${ }^{85}$

Mr. Garrett's statements constitute an obvious espousal of the guardian theory, and a convincing argument for its acceptance, at least where the typical publicissue corporation is involved.

However, there is no unanimity on the validity of the guardian theory even as applied solely to these corporate behemoths. Fundamentally, the active movement for "shareholder democracy," sentation on the board ${ }^{87}$ and increased shareholder participation in policy determinations, ${ }^{88}$ represents a revolution against the guardian philosophy. Two of the leading proponents of corporate democracy adequately demonstrate their philosophical conflict with Garrett:

As suggested by this chapter's title, "Proxy Contests: A Study in Shareholder Sovereignty," contests for proxies are but an expression of the shareholder's traditional and historic corporate sovereignty. Rooted like Thomas Jefferson's political popular sovereignty in the common sense of the common man, the ultimate man who must be relied upon for decision is the common or general shareholder. And if he is to make intelligent decisions, the shareholder must be given sufficient information. The voice of the stockholder, however, must be heard not only in proxy contests, which are relatively rare, but also in the general operation of the corporation, through the proposal rule, and otherwise. For more complete participation by shareholders will increase the sense of his ownership in our economic system. And it will also benefit management by affording it diversity of opinion and criticism so necessary for healthy growth. ${ }^{89}$

For the typical public issue corporation, the board of directors is a necessity. But even for them the guardian theory is not.

${ }^{85} \mathrm{Id}$. at 323-24. See also DruGKER, CONCEPT OF THE CORPORATION (1946). Drucker emphasizes the importance of the corporation to the American economy and culture, and the large corporation as the most important, because it is "the institution which sets the standard for the way of life and mode of living of our citizens." Id. at 6. Taking the General Motors central management as the archetype, he persuasively presents the function of the board of directors as an aristocratic (in the old sense of that term: government by the wise) body able to take the "long view": enlightened social policy as opposed to the immediate profit concerns of ordinary business managers. Id. at 36-39, 49-59, 326-27.

86 See Eunerson \& Latcham, Shareholder Democracy (1954); GiLbert, Dividends AND DesrocRACY (1956); Emerson \& Latcham, Law and the Future: Corporation Law, $41 \mathrm{Nw}$. U.L. Rev 196 (1956). See also Livingston, The AMrerican StockHolder 68-80 (1958).

${ }^{87}$ See Garrett, supra note 84, at 325-27.

${ }^{88}$ Id. at 332-34; EMIERSON \& LATCHAM, op. cit. supra note 86, at 91-117.

89 EMIERSON \& LATCHAM, op. cit. suppa note 86, at 144. 
At the other extreme from the typically mammoth public-issue corporation is the really close corporation, or as it has often been called the "incorporated partnership." With few shareholders, all active in the business, the only reason for choice of the corporate form over a legal partnership is the shield of limited liability. In such a corporation officers, directors and shareholders are often all the same persons.

Such corporations are typically small financially. Latty's "incorporated hot dog stand"90 is an example. The participants have no real knowledge of the differentiation of powers of these various corporate functionaries. To put it more bluntly and perhaps more truthfully, they know not that there is any legal separation between the individuals who carry on the business and "the corporation" itself. ${ }^{91}$ They regard the latter not really as an entity, but merely as a lawyer's paperwork to protect them from personal liability should the business fail.

The "technicalities" of the corporate form of government are normally ignored once the incorporated partners have left the lawyer's office. ${ }^{92}$ This is normal business practice for such incorporated partnerships regardless of whether the laws of the states under which they are incorporated are permissive of such practices, or are, as interpreted by their courts, of the "guardian" type which require that the functions of directors be carried out in strict accordance with a "statutory norm" of proper corporate behavior.

One of the "partners" will order necessary supplies for the business, without stopping to consider whether he has technical authority to do so as secretary, or treasurer, or as the holder of whatever "office" was parcelled out to him to satisfy the requirements of the corporate mold..$^{93} \mathrm{He}$ will tell his co-partners, probably one in the morning and the other in the afternoon when he has returned from a business trip or purchasing expedition, of his act. Each will separately say, "O.K., Joe, whatever you think we need," without stopping to consider whether the purchase requires action by the board of directors convened as a board to authorize the contract. ${ }^{94}$ They may decide to sell a portion of the

${ }^{\circ 0}$ Latty, The Close Corporation and the New North Carolina Business Corporation Act, 34 N.C.L. REv. 432, 453 (1956).

91 This attitude is summed up (in words appropriate to Louis XIV) in the testimony of a stockholder in an early close corporation case: "I own all the stock ... I am the company." Button v. Hoffman, 61 Wis. 20,21, 20 N.W. 667, 668 (1884).

"Ibid.; Barlantane 124; Note, The Close Corporation, 33 N.Y.U. L. REv. 700, 711 (1958).

"3 Yet, the vice-president normally has no authority to bind the corporation. Colish v. Brandywine Raceway Assn., 49 Del. 493, 119 A.2d 887 (Super. Ct. 1955). Nor does the treasurer, much less the secretary. Ibid.; Citizens Development Co. v. Kypawva Oil Co., 191 Ky. 183, 229 S.W. 88 (1921); BALIANTINE 142-43. There are even limitations on the president's powers. Schwartz v. United Merchants \& Manufacturers, Inc., 72 F.2d 256 (2d Cir. 1934); Ballantine 138.

"Yet, the general rule is that action taken by the directors acting individually is void. Baldwin v. Canfield, 26 Minn. 43 (1879); Stevens 656; Ballantine 123; Lattin 219. 
land which they have bought to raise additional cash for their operations. The purchaser's attorney, or their own, if he is called in, will tell them who must sign the deed. The vendee's attorney, if he is wise, may require a copy of the minutes of a shareholders' meeting, ${ }^{95}$ duly certified by the partner who happens to have been picked as secretary. Despite what the piece of paper says there usually will have been no such meeting.

Neglect of these formalities is the rule rather than the exception, as has so often been pointed out. ${ }^{96}$ Yet such neglect may give rise to unfortunate legal consequences in states dedicated to the guardian theory of corporate organization. ${ }^{97}$

It is no real answer to say that the "close corporation" may use some other legal mold, such as the limited partnership, since under the limited partnership the persons who escape individual liability (the object of the incorporated partnership for all its participants) must not become active participants in the management of the business. ${ }^{98}$ Likewise the limited partnership association, which most closely parallels the parnership idea of operation yet grants personal immunity to its participants, is available in only four states. ${ }^{99}$ Because it is not utilized even there (with a consequent dearth of judicial interpretation on its proper management) it is not suggested by prudent lawyers. ${ }^{100}$ Only the corporation remains, therefore, for those who desire active participation in the management of a business and limited personal liability for the business' obligations.

Fortunately, certain limited concessions have been made in the case-law of even "guardian" jurisdictions. For example, in New York, it has been held that "where the directors own all the capital stock of the corporation, where they are members of the same family but so at variance that directors' and stockholders' meetings are not held, their action, concurred in by all, although separately and not as a body, binds the corporation."101 Other courts, too, have shown an

${ }_{95}$ Failure to comply with statutory requirements of shareholder consent may void the transaction. See Leffert v. Jackman, 227 N.Y. 210, 125 N.E. 446 (1946); BallaNTINE 390.

${ }^{96}$ See note 92 siupra.

${ }^{97}$ See notes 93-95 sicpra.

98 UNIFORM LmTted ParTNERSHTP ACT $\$ \$ 2,7$ (1936).

${ }^{99}$ See Mich. Conrp. Laws $\S 20.93$ (1948); Pa. Stat. tit. 15, $\$ 382$ (1916); Ohro Rev. Code ANN. §1783.02 (Baldwin 1959); N.J. REv. Stax. §47:3-3 (1937).

${ }^{100}$ See Latrin 46. Other forms are also unsatisfactory. For example the joint stock company is not desirable since it does not provide limited liability. Id. at 46,48 . The "Massachusetts trust" is not recognized in some states, and has dangers of unlimited liability. Id. at $50-56$.

A single statute with special provisions utilizable only by corporations in which "ownership and management are substantially integrated," has been suggested by one commentator. Note, Statutory Assistantce for Closely Held Corporations, 71 HARv. L. REv. 1498, $1506-07,1511$ (1958). However this is merely the equivalent of having a separate close corporation statute, and objectionable because uncertain or arbitrary.

${ }^{101}$ Gerhard v. Empire Square Realty Co., 195 App. Div. 244, 187 N.Y.S. 306, 310 (1921). See also Petition of Stylemaster Dept. Store, Inc., 154 N.Y.S. 2d 58 (Sup. Ct. 1956); Petition of Kartub, 152 N.Y.S. 2 d 939 (1st. Dept. 1957), and cases cited therein; and the almost shock- 
understanding of the peculiar problems of the close corporation or "incorporated partnership."102

Such concessions by the courts to the problems of the close corporation are however, tentative, limited to and reliant on their peculiar facts, and hence are of no great comfort to those who must advise close corporations on the amount of leeway they may expect from the guardian ideal generally imposed on corporations.

Most of the attention of legal writers has been concentrated on the peculiar problems of the really "close" corporation-the one in which, as a New York authority has defined it, there is an identity of ownership and management. ${ }^{103}$ Many of the authors have suggested that separate statutes be enacted for such close corporations in order to overcome the interpretive uncertainties which exist when the general and largely guardian-type statutes, which are probably enacted not really so much to restrain corporate enterprise as merely to fit the peculiar needs of large public issue corporations, ${ }^{104}$ must be applied to the incorporated partnership.

Although special close-corporation statutes exist in many other countries, ${ }^{105}$

ing statement in Simonson v. Helburn, 198 Misc. 430, 437, 97 N.Y.S. 2d 406, 493 (Sup. Ct. 1950): "[I]t has long been recognized in New York that the directors of a close corporation, when few in number, and in frequent contact with each other may act effectively without going through the useless formality of convening as a board." Unfortunately, higher New York courts cannot be trusted to be as generous.

102 See Annot., 64 A.L.R. 712 (1929).

103 Israels \& Gorman, Corporate Practice 17 (7th ed. 1957):

"There is a basic although sometimes shadowy distinction between what may be called 'close' or 'closed' corporations and 'public-issue' corporations. A close corporation is one in which management and ownership are substantially identical. Conversely, a public-issue corporation is one in which management and ownership are distinctly separate. Usually the distinction is an easy one to draw. The typical one-man or family corporation, and the corporation the stock interests in which are held by two or three partners, most if not all of whom are active executives, are clearly 'close' corporations. To the extent that shareholders are not active in the management, the public-issue corporation aspect grows, and the distinctly personal interests of the participants will be given less weight in devising the capital structure." It is to be observed that such a definition would only include a part of the corporation which under O'Neal's definition would be "close" (all corporations other than those of the public issue variety).

${ }^{104}$ See Winer, Proposing a New York "Close Corporation Law," 28 CoRNell L.Q. 313 (1943); Luna, Protection of Minzority Interests Through Stockholders' Agreements: A Commentary on Section 9 of the New York Stock Corporation Law, 29 Prira. L. J. 506, 535 (1953); Rutledge, Significant Trends in IFodern Incorporation Stahtes, 22 WASH. U.L.Q. 302, 339 (1937) (proposing three different statutes); Note, The Close Corporation, 33 N.Y.U. L. REv. 700 (1958); State of New York Legrslative Document, No. 17, p. 37 (1957). Compare SympositemThe Close Corporation, 52 Nw.U.L. REv. 345, 397 n. 45 (1947).

${ }^{105}$ See, e.g., as to England, The Private Companies Act of 1948; as to France, The Law of March 7,1925 authorizing the Sociéte a Responsibilité Limitée; as to Germany, the Law of April 20,1892 (as amended) authorizing the Gesellschaft mit beschränkter Haftung; as to Japan, the special act authorizing the Yugen Kaisha; as to Switzerland, the Code of Obligations, 772-827. Even our neighbor Canada has such a special statute. 11 Rev. Stat. of Canada, c. 53, \& 3(j). See also Symposium on the Close Corporation, 19 LAw \& CoNTEMr. PROB. 433 (1953). 
the pleas of American proponents of such statutes have gone almost completely unheeded. As will be indicated below, certain concessions to the needs of close corporations have been made within the framework of a few general corporation statutes. However, no American jurisdiction has enacted a separate statute for close corporations despite the repeated suggestions that this be done. Such legislative inactivity probably stems not so much from callousness as from the failure so far of anyone, including the legal writers, to formulate satisfactory definitions that will successfully sort out all corporations which need special treatment from those for which the normal corporate organization and its concomitant formalities are not only welcome but necessary for successful operation. ${ }^{106}$

As indicated above, the most popular criterion for distinguishing between the close corporation, with its special problems, and the kind of corporation for which the corporation statutes of the country seem typically to have been drawn, is whether or not its securities are "generally traded in the securities markets." "107 Under such a definition the great majority of corporations of the country are, of course, close corporations. ${ }^{108}$ While it is obvious that all of the corporations thus made "close" by definitional fiat have some problems in common, it seems clear that the needs of some will be totally different from those of others. To strain all such corporations into conformity with a "close corporation" statute would be as unsatisfactory as is the present majority requirement that all corporations, large and small, "close" and public issue, must conform to a mold primarily suited to only the largest enterprises.

The great discrepancies in size, and the consequent difference in the burdens imposed by corporate formalities, between the incorporated hot dog stand and the very large corporations, though both may be classifiable as close corporations under the prevailing definition, does not indicate so much the inadequacy of that definition as the impossibility of molding one statute which will set a pattern of corporate behavior adequate to all corporations. Even more, they demonstrate the impossibility of enforcing a comfortable conformity to any set statutory pattern, be it a "public issue" statute, or a "close corporation" corset.

There are a number of corporations which are neither the typical close corporation, which is ordinarily small, nor the typical public issue corporation, which is usually mammoth. To produce a statute for all these middle sized corporations, and a separate statute intermediate between it and the statute for the public issue corporations, would be the reductio ad absurdum of any scheme designed to provide a series of fixed molds.

The solution to the problem is thus clearly not two or three separate corporation statutes, since the coverage of each is bound to be based on arbitrary dis-

${ }^{106}$ See Israels, The Close Corporation and the Law, 33 CoRNext L.Q. 488, 491 (1948).

${ }^{107}$ O'NEAI, op. cit. supra note 77, at 5; N.C. GEN. STAT. $\$ 55-73$ (b) (1960).

${ }^{108}$ O'NEAT, op. cit. suppra note 77, at 3. 
tinctions as to, e.g., number of shareholders or amount of capital, ${ }^{109}$ they would, therefore, be no more satisfactory than the present one-mold guardian statutes. The answer is, instead, a single corporation statute which will return to the shareholders the power which they originally possessed-the power to run their corporation in the way they want, and through agents of their own choosing.

There is nothing basically immoral about allowing shareholders to abolish the board of directors and run the corporation for themselves, or in restricting the board's functions in any way they choose. As has been indicated above, the latter is permitted even in restrictive or guardian states like New York, at least where lawyers are clever enough to take advantage of "loopholes" in the law. Some of these "loopholes" have been consciously created by the legislature. ${ }^{110}$ Such official sanction should raise grave doubts about the intent of modern legislatures to do more than merely "bless" present corporate formalities when they use the traditional language conferring the management of a corporation upon its board of directors. But whatever the legislative intent, it is clear that the abolition of the requirement of a board of directors would present to the really small close corporations an uncomplicated way of meeting the real needs of the enterprise. ${ }^{111}$

On the other hand, there is nothing evil in a corporation with only one shareholder having a board of eleven directors. ${ }^{112}$ The choice should be left to those whose interest in good management is the greatest-the corporation's shareholders. ${ }^{113}$ The operation of their corporation should be governed by normal agency principles. There is every indication that the common law sought to allow such arrangements; and probably few legislators would intentionally deny them. The shareholders ought to be able to choose their agents, whether they are called "directors," "officers," "managers," "trustees," or simply "employees," and confer upon them what powers they choose, and subject them to such limitations of power as they may desire to impose. ${ }^{114}$

Many courts seem to have a very low opinion of legislators. They impute to

${ }^{109}$ For example, the English, Canadian and Japanese statutes all limit the private company to a maximum of 50 shareholders. Supra note 105 . See also, P.R. LAws ANN. tit. 14, $\$ 1102$ (c) (Supp. 1959). Puerto Rico restricts its close corporation ambit to corporations with no more than 11 shareholders. To have no maximum limits on the corporations which may choose special treatment (as appears to be the case, e.g., with the French, German and Swiss statutes) is the equivalent of having one statute with optional provisions such as is suggested herein.

${ }^{110}$ E.g., N.Y. Stock Corp. LaW $\S 9$.

"111 How much simpler, for example, to allow the one man corporation to be run by that one man without resort to dummy directors and high vote requirements.

112 In Baldwin v. Canfield, 26 Minn. 43 (1879), for example, there was only one shareholder, but a board of 11 directors. If it suits his needs, a sole shareholder should be allowed to have as large a board as he wants, or no board at all.

113 See Note, Statutory Assistance for Closely Held Corporations, supra note 100.

114 Provided, of course, that the corporation is held to normal agency rules (including liability for conferring ostensible authority), and preferably also to an "indoor management" rule. See Stevens 773-76. 
them the power motives of tyrants and dictators. Clearly the state may impose conditions on the privilege of incorporation, if it chooses to do so. It could compel labor representation in the management of the corporation. It could provide for impeachment of corporate officers at the hands of the state senate. It sould require that the president of the corporation be over 65 years of age, or under. Any number of a myriad of burdens could be imposed. They would be legal. The courts, attempting to read the minds of the legislators, have apparently found in them the intention to impose a number of similar, if slightly less arbitrary, obligations on those hapless businessmen who want to "buy" the privilege of limited liability.

It is not difficult to have more faith in legislatures than our courts appear to have. There is no reason to impute to them an intent to exact conformity merely for its own sake. The judges might well credit the legislatures with the same fine sensibility they apply to themselves: "Let us consider the reason of the case. For nothing is law that is not reason."'115 What is the reason for compelling a guardian type of corporate organization and management where it is unsuited to the needs of the individuals involved?

The state, of course, has an interest in the management of corporations, and it should protect this interest. But what is this interest? Manifestly it is not conformity to the statutory norm for its own sake. The interest of the state is in reality the balanced interests of the creditors, shareholders and employees of the corporation. The state can have no interest in the form of corporate management where no one of the groups to be protected has been injured. It is difficult to conceive what special injury to any of these flows from even a "sterilized" board of directors, or the use of officers or any other agents however titled in their stead, for whose acts the corporation is willing to accept responsibility.

It is certainly an unwarranted insult to consider legislatures as less reasonable than judges. To impute to them a motive to restrain without reason is, in short, to accuse them of totalitarianism. Yet it must be admitted that the legislatures of the country have done little to correct what, considering their apparent contemporary intent and even the ancient intent imputed to them by the common law, can only be a misinterpretation of their words by recent guardian-minded courts.

As was indicated at the outset, the A.B.A. Model Business Corporation Act, despite the fact that it is designed to provide "state commissions and bar association committees with a working model for revision and modernization of their corporation laws, ${ }^{\prime 116}$ preserves the language of almost all previous American corporation laws which have not only been held to make the existence of a board of directors mandatory, but also any encroachment on its powers by the shareholders void. Aid and comfort to the erroneous, conceptualistic guardian

${ }^{115}$ Sir John Powell, in Coggs v. Bernard, [1703] 2 Lord Raymond 909, 911, 92 E.R. 107, 109.

116 Preface to ALI-ABA MoDer Bus. CoRp. ACT at iv (ed. 1950) [Emphasis added]. 
theory of corporation structure has thus been given by the very people who purport to show a way of modernizing corporate laws to recognize the proper rights and interests of corporations, shareholders and management. ${ }^{117}$ This proposed anodyne for corporate law ills has already been substantially enacted in nine American jurisdictions, ${ }^{118}$ and has also had an influence on other recent statutory revisions.119

Therefore, by following the Model Act pattern (as to the subject of the board of directors at least), the legislatures of the country have shown a retrogressive attitude, pointing toward the guardian theory, instead of one directed to the actual needs of the corporation and the classic common law theory that the problems of corporate management were ultimately for the shareholders to determine.

In addition to requiring a board of directors, the Model Act supplies even further indication of support of the guardian theory by giving good evidence that the board must act in a formal fashion. Although notice of meetings may be waived, ${ }^{120}$ there is no authorization for action of the directors, despite unanimous approval, without a formal meeting. Such a concession to informal action is granted to the shareholders; ${ }^{121}$ but the comment to the statutory permission that "any action required by the Act to be taken at a meeting of the shareholders of a corporation, or any action which may be taken at a meeting of the shareholders, may be taken without a meeting if a consent in writing, setting forth the action so taken, shall be signed by all of the shareholders entitled to vote with respect to the subject matter thereof," and that "the Act does not authorize any similar informal procedure for directors," makes it clear that directorial action must be taken at a regularly convened meeting. ${ }^{222} \mathrm{~A}$ court interpreting such statutes would be justified in holding, in harmony with the guardian theory, that any action by directors not taken at such a formal meeting was void.

Such have been the holdings under earlier statutes; ${ }^{123}$ and since clear lan-

${ }^{117} I d$. at $x$.

118 Prentice-Hall Corporation Letter, August 24, 1959.

"19 Maryland, North Carolina, and even Ontario and Japan have been influenced by the Model Act, as has Pennsylvania, the latter through the Model Act's progenitor, the Illinois Business Corporation Act. See Campbell, The Moder Business Corporatron Act, 11 Bus. LAw. 98 (1956). It was also used as the research framework for the recent studies undertaken by the State of New York in connection with its project to revise the corporation laws of that state. State of New York, Legislative Docusient No. 17, p. 96 (1957). See also State of New YoRk, Legiscative DocunEent No. 23, pp. 31, pp. 31, 66, 97 (1958).

${ }^{120}$ ALI-ABA MODEL BUS. CoRP. ACT $\S 137$ (1953).

131 Id. at $\$ 138$.

222 Id. at $\$ \$ 37,39$.

${ }^{123}$ See Baker \& Cary, Cases aNd MLATERIals on Corporations 115 n.2 (3d ed. 1959); Stevens 656-62; LatTin 216-22; Ballantine 123-25. Some states have, fortunately, made concessions by case or statute law. See notes 124-26 infra. 
guage "expressly or through unavoidable implication"124 changing the interpretation placed on an earlier statute is required to override that earlier judicial interpretation, it is obvious that some courts will, even under these "modern" statutes, impose a guardian theory to invalidate corporate action on the technical ground of nonconformity to the statutory norm. Wiser courts, like those in Gerard v. Empire Square Realty Co ${ }^{125}$ and Sherman v. Fitch, ${ }^{126}$ will be pushed to contrive some theory of estoppel to uphold the validity of corporate contracts entered into without scrupulous adherance to the ritual required by a "face" meaning of such statutes. Their motive will be to avoid the manifest injustice to outsiders dealing with the corporation which results from rigid enforcement of the guardian theory.

It is, of course, ridiculous to pass statutes which must either cause injustice or judicial circumvention. Such, however, seems to be the result of even the most "modern" of corporation statutes. It is ironic that a specious interest of the state may thus be used to defeat the real interest of the state in the protection of creditors by enforcement of corporate contracts-even those not technically approved by the corporation with the formality required under a carry-over of the guardian theory.

A few jurisdictions, however, including some of those whose statutes were influenced by the Model Act, have made clear at least a qualified rejection of the guardian theory of corporate management. They allow not only informal shareholder action, but also informal director action, ${ }^{127}$ under the same condi-

124 Woollcott v. Shubert, 217 N.Y. 212, 220, 111 N.E. 829, 836 (1916). Reenactment of the previous statutory language, unchanged, in effect enacts the previous judicial interpretation of that statute. See Apex Hosiery Co. v. Leader, 310 U.S. 459 (1940).

125195 App. Div. 244, 187 N.Y.S. 306 (1921).

12598 Mass. 59 (1867). A corporate mortgage executed by a president-director was upheld against attack by the creditor's representative in insolvency despite a lack of formal authorization of the mortgage by the board of directors, and despite the fact that one of the four directors was in Europe, and hence did not have knowledge of the transaction.

${ }^{127}$ Des. Code. ANN. tit. 8, $\$ 141$ (g) (1953); MD. ANN. Code art. 23, $\$ 54$ (1957); N.C. Gen. Stat. § 55-29 (1960); Oho Rev. Code ANN. § 1701.54 (Baldwin 1958); Pa. Stat. tit. 15, $\$ 402(5)(1958)$. North Carolina goes even further. In addition to authorizing informal action upon unanimous consent, it provides that:

"Informal or Irregular Action by Directors or Committees.-(a) Action taken by a majority of the directors or members of a committee without a meeting is nevertheless board or committee action if:

"(1) Written consent to the action in question is signed by all the directors or members of the committee, as the case may be, and filed with the minutes of the proceedings of the board or committee, whether done before or after the action so taken, or if

"(2) All the shareholders know of the action in question and make no prompt objection thereto, or if

"(3) The directors or committee members are accustomed to take informal action and this custom is known to the shareholders and if all the directors or committee members, as the case may be, know of the action in question and no director or committee member makes prompt objection thereto.

"(b) If a meeting of directors otherwise valid is held without proper call or notice, action taken at such meeting otherwise valid is deemed ratified by a director who did not attend unless 
tions: written consent by all of the parties who have a vote on the matter. Three states even extend such permission to act informally to committees of the board: Maryland, ${ }^{128}$ North Carolina ${ }^{129}$ (whose statute although purporting to base itself on the Model Act has been disclaimed by the latter's proponents because of significant deviations from that paradigm), ${ }^{130}$ and Delaware ${ }^{131}$ (deservedly the most popular incorporation state ${ }^{132}$ because of its manifest, and at times even overenthusiastic, ${ }^{133}$ concern for the problems of the corporation). Clearly all of these statutes are an improvement over both the Model Act and the earlier statutes which have, probably because of inept drafting rather that conscious intent, given rise to the guardian theory. Even though they are, of course, minor attempts to return the directors of a corporation to their original status as agents of the shareholders, they are nevertheless welcome.

The North Carolina act goes even further. At least for the "close corporation," it appears to allow any restriction by the shareholders on the powers of the board of directors which the former may desire, short of total abolition of the board. ${ }^{134}$ This is an improvement, but it still falls short of the ultimate advance called for.

Only four jurisdictions in this country have taken the obvious step, that of allowing a corporation the choice of leaving its management completely with its shareholders if its particular needs so require. They are Arizona, ${ }^{135}$ Iowa, ${ }^{136}$ Mississippi ${ }^{137}$ and Puerto Rico. ${ }^{138}$ Unfortunately, unqualified commendation may not be given to even these four jurisdictions.

The Mississippi statute, it is true, does not expressly require the existence of

promptly after having knowledge of the action taken and of the impropriety in question he files with the secretary or assistant secretary of the corporation his written objection to the holding of the meeting or to any specific action so taken." N.C. GEN. STAT. $\$ 55-29$ (1960). The Delaware provision is not completely satisfactory for a state so noted for its corporate sympathies, since it requires that the written consent be executed prior to the action taken."

123 MID. ANN. CODE art. 23, §54 (1957).

129 N.C. Gen. StAt. \$ 55-29 (1960).

${ }^{130}$ Campbell, The Model Business Corporation Act, 11 Bos. Law 98, 109 (1956).

131 Dex. Code ANn. tit. 8, §141(g) (1953).

${ }^{132}$ As to its popularity, see Fortune, Supplement, July, 1956.

${ }^{133}$ For example, it seems clear that in such cases as Shanik v. White Sewing Mach., 25 Del. Ch. 371, 19 A.2d 831 (1941), and Federal United Corp. v. Havender, 24 Del. Ch. 318, 11 A.2d 331 (1940), the Delaware courts sacrificed the welfare of corporate shareholders in their eagerness to favor management. See also Hottenstein v. York Ice Mach. Corp., 136 F.2d 944 (3d Cir. 1943).

134 See N.C. GeN. Stat. $\$ \S 55-73(b)$, 55-73(c), 55-24 (1960).

${ }^{135}$ See Ariz. REv. Stat. ANN. \$10-122(7) (1956).

${ }^{136}$ See Iowa Code $\$ 491.5(5)$ (1958).

${ }^{137}$ See Mrss. Const. art. 7, §194.

${ }^{138}$ See P.R. LAws ANN. tit. 14, $\$ 1102$ (Supp. 1959). 
a board of directors. However, the existence of such a board of directors (or "managers," similarly functioning as a board) seems to be assumed. For example, the Mississippi Constitution requires cumulative voting for "directors or managers";139 the corporate charter, although it need not specify the names, numbers or powers of the directors, may specify "the sale price per share, if desired, of stock without par value, and authority for the board of directors to fix or change such sale price, if such authority be desired." 140 No alternative is provided should the board be dispensed with; and both the statutory provision relating to corporate elections ${ }^{141}$ and that relating to corporate loans ${ }^{142}$ seem to assume the existence of such a board. ${ }^{143}$ Despite these indications that the existence of a board of directors is contemplated for every corporation, the Mississippi statute must be commended in this regard. It does give a courageous close corporation good statutory justification for dispensing with the board of directors should it choose to gamble that the Mississippi courts will be less guardian-minded than those of most of the other states, and that they will abide by the statute's "face" meaning.

The Iowa statute is less ambiguous. It has, however, recently been scorned by the legislature which has enacted the Model Act as a "new" corporation law for the state. The old statute remains effective for corporations-even presently unformed corporations-which elect to utilize it.144 The "old" statute requires only that the certificate of incorporation state "names and addresses of the incorporators and the officers or persons its affairs are to be conducted by, and the times when and manner in which such officers will be elected."145 Inferentially, the customary requirement that the business of a corporation shall be managed by its board of directors seems to be omitted. The shareholders are thus given the choice of managing the corporation for themselves, or of selecting the officers to do so without the intervention of a board of directors.

The Arizona provision is even more succinct than the old Iowa law. It merely requires that the articles state: "by what officers the affairs of the corporation are to be conducted, and the time of their election." 146 That the board is dispensible is indicated by the express provision that:

The term "director" as used in this article embraces any of the persons having by law the direction or management of the affairs of a corporation or association, by whatever name such persons are described in its charter or are known by law. ${ }^{147}$

${ }^{139}$ Miss. Const. art. 7, $\S 194$.

${ }^{140}$ Miss. Code ANN. $\$ 5310$ (1957).

${ }^{141} I d . \$ 5326$.

12 Id. $\S 5330$.

${ }^{143}$ See also $I d$. $\$ 5312$ (providing for out-of-state directors' meetings).

${ }^{144}$ IowA CoDe $\$ 496 \mathrm{~A} .142$ (Supp. 1959).

${ }^{145}$ Iowa CoDe $\S 491.5(5)$ (1958).

${ }^{146}$ ARIz. Rev. Stat. ANN. § 10-122 (Supp. 1959).

${ }^{147}$ ARIz. REv. Stat. ANN. § 10-191B (1956). 
This is a clear demonstration that omitting the requirement of a board of directors was not a mere legislative oversight, but instead that the lawmakers positively (and approvingly) contemplated that some corporations would choose not to be governed by such a body.

Unfortunately, even Arizona provides a few straws to which the guardian theorists may cling. For example, although the above provision clearly states that the term "director" is merely a convenient equivalent for any corporate agent that the corporation may choose, this provision is unfortunately appended as a subsection to the first section of an article dealing with knowledge imputed to the corporation through its directors. And although other sections of the article refer to "directors, officers or agents," 148_-one section even omits the title director, using instead "officer, agent or clerk,"149-one section, dealing with fiduciary duties, uses only the term "director."150 Manifestly, a proper interpretation of this last section would carry over the definition of director which includes "any of the persons having by law the direction or management of the affairs of a corporation," since that definition is made applicable to the entire article not merely to the section in which it appears. A guardian-minded court might, however, erroneously conclude otherwise.

Despite these defects, it should still be clear to any court honestly seeking the legislative intent that it is the will of the Arizona legislature that a board of directors is not to be forced upon any Arizona corporation which feels it can do without one. Only a very slight improvement in expression would be necessary to administer the coup de grace to even the most intransigent guardianists.

The Puerto Rican statute is the most explicit of all in its permission to corporations to dispense with the board of directors, if they feel that it would be to their advantage:

[T] he certificate of incorporation may also contain a provision that the corporation shall have not more than a stated number of stockholders at any one time which stated number shall be not more than eleven (11). A Certificate of Incorporation containing such a provision may, notwithstanding any of the provisions of chapter 104 or chapter 107 of this subtitle, contain ... a provision or provisions that the business of the corporation shall be managed and conducted by its stockholders who may then exercise the powers and functions of a board of directors and, if desired, a provision or provisions setting out the manner of such conduct by them or any one or more of them, and such provision may empower the stockholders to authorize an officer or officers or an agent or agents to manage and conduct the business of the company. Such authorization shall be given by instrument in writing signed by all of the stockholders and may contain such terms, provisions and conditions and may grant such limited or unlimited power and authority as the stockholders may choose to insert. The stockholders may from time to time alter the terms, provisions and conditions of any such authorization by like instrument in writing; provided, however, that any such authorization shall be revocable by instrument in writing signed by the holders of a majority of the shares,

${ }^{248}$ Id. §§ 10-192, 10-193, 10-195.

14 $1 d$. $\$ 10-194$.

${ }^{150} I d . \$ 10-196$. 
from and after three calendar years from the date of its execution unless an earlier date of revocability shall have been fixed in authorization. Whenever and so long as a corporation whose certificates of incorporation limit the number of its stockholders pursuant to this subsection (c) shall at any time have only one stockholder, such stockholder shall have full power to manage and conduct the business and affairs of the corporation. ${ }^{151}$

Because of its greater clarity of expression, the Puerto Rican statute is preferable to the Mississippi, and even the Iowa and Arizona, statutes. It is, of course, far superior to the North Carolina statute which, although it makes express the shareholders' right to restrict the powers of the board of directors, does not take the full step: authorization of its abolition. Thus, like the United States Electoral College, the board of directors is preserved as a useless and atrophied appendage to corporations which have no need for its services. ${ }^{152}$

On the other hand, the Puerto Rican statute is not really a satisfactory solution to the problem, not only because a mere majority can "break up" the management arrangement after three years by terminating the authorization of the agents to run the corporation, but also because it relies on an arbitrary distinction. Only a corporation with eleven or fewer shareholders has the privilege or eliminating the board of directors. As indicated above, an adequate solution to each corporation's problems should give the corporation itself the right to decide whether it wants to utilize or dispense with a board of directors. It is, of course, quite true that corporations of over eleven shareholders will rarely want to dispense with the board. For corporations with more than a few shareowners the board is often as much of a simplification of corporate management as is dispensing with a board for those corporations which have a very small number of shareholders. However, this is not necessarily true; and even if some centralized management is necessary, why not only one man, called a "director," "manager" or "president," instead of the customary minimum three-man board? Further, why not have him selected directly by the shareholders themselves, if they choose, rather than by a group of intermediaries? In short, the entire question of internal corporate management should be left completely within the discretion of the true parties in interest, the shareholders.

Despite their shortcomings it must, however, be granted that concessions have been made by all five of these statutes to basic corporate needs. They are, therefore, welcomed by those who feel that the incorporators are the ones to decide how their corporation is to be run. The only criticism is that each fails to go far enough. They are all clear repudiations of the guardian theory and a return to the common law conception of directors as mere agents of the shareholders. Corporate control is, within the respective limitations of these laws, given to those to whom it really belongs; the "spirit" of these laws is willing, the drafting flesh is weak.

151 P.R. LAws Ann. tit. 14, § 1102 (Supp. 1959) (Emphasis added).

${ }^{152}$ Provisions of the North Carolina Statute seem to require a board. N.C. GeN. Stat. $\S \S(55,-24$ 55-25 (1960. 


\section{A Proposed Statute}

\section{Board or No Board}

A really adequate statute would unequivocally give the choice of the form of the management to the shareholders, the shareholders' representatives, the "incorporators, ${ }^{\prime 153}$ or the promoters of the enterprise. For example, the statute might provide that "the business and affairs of a corporation shall be managed by such officers and agents, however denominated, and under such terms and conditions as the certificate of incorporation, or by-laws duly enacted by the shareholders shall prescribe." An express exemption from having a board of directors should probably be added to overcome judicial reluctance to abandon the guardian theory. For example, the statute, or a legislatively authorized comment thereto, might state: "A corporation is hereby expressly authorized to dispense with a board of directors, if it chooses to do so, and to confide its management to other agencies, or to retain all management functions in the shareholders." Such an addendum should be sufficient to make clear the legislative purpose to even the most sclerotic of judges.

\section{Shareholders' Agreements}

An adequate provision would also provide for the enforcement of shareholders' agreements as to management of the corporation, even though not formally embodied in the certificate or bylaws. The only question is whether the agreement by the shareholders should have to be unanimous (as, e.g., is required in Puerto Rico ${ }^{154}$ ). In very small corporations, of course, such an agreement will normally be approved by all of the shareholders. There would seem to be no reason, however, why a majority-shareholder agreement should not be equally enforceable, since the majority of shareholders even in a corporation with a board of directors, and, even under such restrictive statutes as that of New York, have the power to effectively manage the corporate affairs, substituting their will for that of the directors through their power of amotion. What the law permits by indirection, it should allow expressly in order to avoid the necessity for resort to "technicalities" and the concomitant stigma placed on the law as an occult science wholly divorced from justice. Therefore, the statute should also allow the corporate management form to be determined by a majority shareholder agreement even though not sanctified by inclusion in the certificate or bylaws, provided that the existence of such an agreement is made known to all prospective investors. ${ }^{155}$ "Constructive" notice through filing with

${ }^{153}$ The "incorporators" will, of course, usually be dummies. See ISRAEIs \& GoRmaN, Corporate Practice 53 (1957). Since they will generally be employees of the incorporating attorney they may reasonably be expected to "enact" provisions meeting with the approval of the real owners of the enterprise.

154 See pp. 727-28 supra.

${ }^{155}$ But see Note 71 HARv. L. Rev. 1498, 1509 (1958), suggesting that the adoption of shareholder veto arrangements should require the same percentage vote as is necessary for "a fundamental change in the corporation." The author adds that this will, in most states, be 
the corporation (similar to that required for a voting trust) ${ }^{156}$ should be sufficient to protect the rights of minority shareholders.

The same considerations should apply with respect to shareholders' agreements which merely bind the directors' discretion where a board has been set up, even though they so limit that discretion that the board may be said to be "sterilized," i.e., completely subservient to the agreeing shareholders' will.

Regardless of the size of the corporation, such agreements should be valid, at least if all the non-signing shareholders or prospective shareholders have notice of them, even though certain or all of the directors are parties to the agreement and surrender their discretion thereunder. After all, an organized majority of shareholders, except in states where cumulative voting is mandatory, will be able to elect the entire board; and even in states where cumulative voting is required, the majority will normally be able to elect a controlling number of the members. ${ }^{157}$ It is also totally unrealistic to assume that a board so elected will not ordinarily be entirely subservient to the wishes of those upon whom their positions depend. It is utterly ridiculous to assume otherwise where a power of removal without cause exists.

It is to be observed that, in the hands of an overly "liberal" (i.e., permissive)

two-thirds. Note, however, that at least three recent statutes allow such a fundamental corporate change as cancellation of accrued dividends by a mere majority (class) vote. See Gibson, How Fixed Are Class Shareholders Rights?, 23 LAW \& Contesur. Prob. 283, 293 (1958).

${ }^{156}$ See, e.g., Des. Code ANN. tit. 8, \$218(a) (1953); N.Y. Stock Corp. IAW § 50; ABAALI ModeI BUS. CoRp. Acr. $\$ 32$ (1953); Note, 71 Harv. L. REv. 1498, 1508 (1958). See also Nickolopoulos v. Sarantis, 102 N.J. Eq. 585, 141 A.792 (Ct. Err. \& App. 1928). Of course, the certificate of incorporation should be allowed to prevent any such arrangement, in accordance with the general theory that a corporation should be allowed to do what it wants, provided that none of the interests which a corporation law should protect are harmed. The assumption typical of our law, that constructive notice constitutes protection is, of course, implicit.

${ }^{157}$ This is clear from the formula for computing the number of shares requisite to elect a given number of directors out of any given board. See Wurtams, CoMrolatrve VotnNg for DrRecrors 40 (1951). The formula for guaranteeing the election of a specific number of directors is $\mathrm{X}=(\mathrm{Y} \times \mathrm{N} 1 / \mathrm{N}+1)+1$, where $\mathrm{X}=$ the number of the shares necessary to elect the desired number of directors, $\mathrm{Y}=$ the number of shares outstanding, $\mathrm{N} 1=$ the number of directors desired to be elected, and $\mathrm{N}=$ the total number of directors to be elected. It follows from this that 51 of 100 shares will elect two out of a three man board, even where cumulative voting is allowed.

Of course, even where cumulative voting is required, its object-minority representationmay often be completely circumvented. See Janney v. Philadelphia Transp. Co., $387 \mathrm{~Pa}$. 282,128 A.2d 76 (1956). Since the formula for electing at least one director by a shareholder under cumulative voting is $X=(Y / N+1)+1$, it is, of course, simple to regulate either the number of minority shares $(\mathrm{X})$ or the number of directors $(\mathrm{N})$, and thus prevent the minority shareholder from getting the representation on the board which cumulative voting is designed to provide him. By changing the "+" to a "-" in the formula the result would be assured, where $\mathrm{X}$ then becomes the maximum number of shares to be allowed to the minority. Thus it will be possible with a three man board (even without classification according to terms of office) to completely deprive a holder of one out of ten shares of representation on the board where the other 9 shares vote together. This, of course, provides yet another example of perfectly legal means by which the notion of the board of directors as a governmental group independent of shareholder control may be circumvented. 
court, such ambiguous provisions as that in the North Carolina statute ${ }^{158}$ might neglect this legitimate interest of the minority (non-signing) shareholders in having a fair knowledge of the terms of their investment. Such statutes as that of Iowa might well be construed by guardian-minded courts as forbidding any restraints upon the powers of the board of directors, once the incorporators had decided that use of the board was preferable to requiring a shareholders' meeting for every minor business decision, or had adopted the simpler but more dangerous expedient of confiding all corporate decisions to the officers without immediate committee controls.

A really adequate statute should expressly grant to any shareholders whose stake in the corporation would, under normal voting rules, give them the power of control-the enforceable right to manage the corporation as they chooseeven though their management plans are not set forth in the certificate or bylaws. Provision should be made for excluded investors to have a fair chance of appraising themselves of the terms of the private agreement, and thus of making their choice to invest with full cognizance of the risks they run. The statute should add, therefore, that "any shareholders' agreements, though not consented to by all or even a majority of the shareholders, shall nonetheless be enforceable among the signatories thereof and those in privity with them, even though said signatories may be directors of the corporation, and whether or not said directors are shareholders, provided that the agreement has been filed with the corporation; that notice of the filing of said agreement is given by the parties to said agreement to each shareholder of record at the time of the filing; that the agreement is open to examination at the office of the corporation during normal business hours on any business day by any shareholder of record or person authorized in writing by a shareholder of record to examine the agreement; and that notice of the existence of the agreement be placed on every certificate of stock of the corporation, whether or not the holder thereof is a signatory of the agreement. The costs of fulfilling the requirements of notice shall be borne by the signatories of said agreement."

The purpose of the authorization provision is to enable prospective purchasers of the stock to examine the agreement should they choose to do so. The requirement for notice on the certificate is to inform them of the existence of the agreement so that they may apprise themselves of their rights and possible liabilities thereunder ${ }^{159}$ before purchase. Such provisions are, of course, accordant with the requirements of fair notice where the transfer of the stock itself is restricted. Since control provisions and stock transfer limitations are

${ }^{158}$ It is to be observed that the statute only impliedly requires unanimous consent for shareholder agreements restricting board action. N.C. GEN. STAT. $\$ 55-73(1960)$. See generally Latty, The Close Corporation and the New North Carolina Business Corporation Act, 34 N.C.L. REV. 432 (1956).

- ${ }^{159}$ Should the agreement, e.g., also encompass restrictions on the transferability of shares of the signatories thereof. 
usually included in the same shareholder agreement, these requirements are well suited to protect the interests of transferees with respect to both problems.

It is to be observed that such a statute would provide a much more adequate solution for the problems of intra-corporate management by the shareholders even where they have been chosen to set up a board of directors than is presently available under the various techniques which have been attempted as necessary devices to avoid the current guardian theory of the board of directors. For example, no longer will failure to meet the statutory letter for a voting trust completely frustrate shareholder agreement. ${ }^{160}$ Open and direct control will be acknowledged.

The suggested provision with regard to shareholders' agreements would make it clear that such agreements for corporate control would not be invalid, even though they failed to comply with the formal statutory requirements of a voting trust, and even though they gave broader management powers than are available under statutes allowing such trusts. For sclerotic judges, a special provision or comment to the effect that no such agreements are to be held invalid as effective voting trusts would be advisable. Such a statute would make effectively enforceable ${ }^{161}$ such agreements as those in Ringling Bros. Barnum \& Bailey Combined Shows v. Ringling, ${ }^{162}$ and Abercrombie v. Davies. ${ }^{163}$ The latter decision frustrated the attempt of a group of shareholders' to retain control of corporate management. The proposed statute would recognize the "irrevocable proxy" given the majority to vote the shares of all sgnatories to the agreement on all matters covered by the agreement, including election of directors and enactment of corporate legislation controlling their action..$^{164}$ Although the words of the suggested provision seem clearly to indicate such a legislative purpose, here again an appropriate "comment" would seem advisable for recalcitrant judges.

In short, an adequate statute would provide for the absolute enforcement of all shareholders' agreements with regard to corporate management, to the ex-

${ }^{160}$ See e.g., Abercrombie v. Davies, 130 A.2d 338 (Del. Super. 1957).

${ }^{161}$ In the worst guardian-minded states the word "specifically" should be added before the word "enforceable" in the suggested statutory provision.

16229 Del. Ch. 610, 53 A.2d 441 (Sup. Ct. 1947). The Supreme Court of Delaware, although purporting to enforce a shareholders' agreement for election of directors, in effect rendered the agreement nugatory by refusing to count votes cast by the arbitrator (chosen by the agreement) in conflict with the wishes of one of the shareholder parties thereto.

${ }^{163} 130$ A.2d 338 (Del. Super. 1957). In both the Ringling and Abercrombie cases the courts refused to recognize that the agreements conferred an irrevocable proxy on the persons designated in the agreement to vote in case of disagreement among the shareholders. New York's restrictive irrevocable proxy statute (N.Y. STOCK CoRP. LAW \$47-a) would seem to make a similar result inevitable in that state. Abolition of the board and operation of the corporation through a committee in which decisions would be made according to the relative voting power of the shareholder principals of the delegates would obviate all such problems.

${ }^{164}$ See, e.g., N.C. Gen. Stat. $\$ \S 55-16(a)(2), 55-16(a)(4)(1960)$; N.Y. Gen. Corp. Law $\S \S 14(5), 27$. 
tent of the combined voting power of the parties to the agreement, provided only that outsiders are given notice of the control arrangement of the corporation before choosing to invest their money in the enterprise.

\section{Other Necessary Statutory Adjuncts to the Abolition of the Guardian Theory}

A statute which would expressly allow the abolition of the board of directors and the selection of other shareholder agencies to perform the functions normally confided to this group would ordinarily appear to be sufficient to empower the shareholders to set up another group of "agents" subject absolutely to their will and removable at their pleasure for disobedience. In the absence of the clearest of legislative expressions, however, one can never be sure that these "agents," however characterized, will not be consecrated a "board of directors" by unsympathetic or incompetent judges, with the result that despite an enlightened legislature, and in direct violation of its real intent, a group of guardians will again be foisted upon the hapless shareholders.

To obviate such a result, not only should the express statements of intent suggested above be incorporated in the new legislative enactments, but the statute should also make clear the power of the shareholders to pass bylaws controlling the action of all their agents, including "directors." Furthermore, the inviolability of these shareholder bylaws from directorial action should be made clear. The statute should also expressly allow to the shareholders their common law right to dismiss any agents who meet with their dissatisfaction under such terms and conditions as the shareholders may establish. ${ }^{165}$ The shareholders should be allowed to enter into a contract limiting their removal right, or to pass a bylaw with such high vote requirements for change that the agent's position will be as inviolable as that of a director under present guardian holdings. Likewise, the statute should authorize the shareholders to make their own choice with regard to filling vacancies among the agents (including, of course, again, the directors).

The combined effect of such statutory provisions will be to allow to shareholders, if they so choose, and subject to negotiation with the agents themselves, the power immediately to remove agents who fail to carry out their will, and to replace them, with the same alacrity, with persons who are appropriately aware of the true subordinate status of all corporate agents.

For corporations which choose to retain the Platonic ideal of corporate organization there should, of course, be a "default" law incorporating contemporary legal rules, which will apply in the absence of a choice by the shareholders to dispense with these rules. These sections must be very carefully drawn, however, to make it clear that no shareholder agreement to avoid the effect of this default law is to be considered invalid. The importance of crystal clear expression

${ }^{165}$ It is interesting to note that often such power of summary removal is conferred upon the board of directors with regard to corporate officers. Why not upon the shareholders vis-à-vis all corporate agents, including directors? See BALLANTINE 436. 
in this regard is amply demonstrated by the short-sighted judicial interpretation in the.Benintendi case ${ }^{166}$. of what might well have been intended as a similarly permissive provision.

There are, of course, many other sections of the statutes which would have to be altered to make certain the achievement of what should be one of the primary purposes of any worthwhile corporation law: the return to the common law rule of a corporation by. its true owners, its shareholders.

- One specific suggestion for modification of even the "default".law ${ }^{167}$ might be made. There is-no reason, except the guardian theory, why the directors, even where this form of corporate management is selected, should have to meet as a board to decide corporate problems. Such a requirement is a direct deduction from the guardian hypothesis, and can be justified under no other theory. Presumably, it is designed to insure an exchange of opinions and due deliberation on all sides of the issue. One can envision the disastrous consequences which would result if such a theory were rigorously applied to the prototype of the board of directors under the guardian theory - the United States Senate. There would be no "pairing off" and no more "quorum calls" for those who got a bit bored with their colleagues' speeches. The members of the board may be just as interested in the affairs of the corporation when they are not gathered around a table to vote as when they are. Their respective views may be as well known to one another, thanks to the telephone, as if they were all in one room.

The executive committee is a recognition of the onerousness of gathering together the entire board in one place for a formal meeting. The burden is far greater for a large corporation, the members of whose board, since chosen for their ability, are selected from all parts of the nation. Again, if the corporation chooses, what the law allows by indirection should be expressly permitted without resort to loopholes. Even the guardian ideal of total decisional particition is better served by a multi-party telephone conference than by allowing circumvention of the deliberative ideal through executive committees.

The law should, of course, allow the corporation to dispense with all formal requirements, including that of a meeting, if the shareholders so choose. But even the "default" law-the law for corporations not so electing special treatment-should at least provide for board "meetings" through the medium of simultaneous multi-party telephone conversations, or unanimous written confirmation of proposed actions.

\section{ConCLUSION}

It is not reasonable to presume that any democratic legislature really intends to pass a law without a rational basis. Arbitrary restraint is not a part of our tradition. Our corporation laws, like all others, should have a foundation in reason. When we say that the state has an interest in corporate

${ }^{166}$ Note 11 supra.

${ }^{167}$ I.e., the law for those who do not choose to "opt out." 
operations, we are merely saying that harm to the public must be prevented. The "state," therefore, has no interest in the forms of intra-corporate organization and management, except to the extent that they somehow harm the shareholders or third parties dealing with the corporation.

As to the shareholders, however, the danger is slight. In most corporations which will choose to abolish the board of directors, all of the shareholders will consent to this simplification of management, since it clearly will be advantageous to them to do so. However, where existing corporations choose to take advantage of the permission granted under the proposed enactment, if less than a majority are opposed, the minority is certainly no more harmed than it is under the Model Act and its variants. These statutes allow an increase in the number of directors by the board itself-an effective way of permitting the majority shareholders, through "their" directors, to "pack" the board, thus attaining the same result as would be achieved by a complete abolition of the board. ${ }^{168}$ Furthermore, since officers and other agents are held to the same fiduciary duty as are directors, the shareholders have no reason to fear the displacement of the board on this account. ${ }^{169}$

Third parties dealing with the corporation will not be harmed by the abolition of the board, since the common law has already developed rules to protect them in their dealings with a corporation in which the board of directors has abdicated its functions. Cases have held that where the board has surrendered its usual powers to executives (even though only by acquiescence), these agents have sufficient power to bind the corporation despite the absence of a formal grant of authority. ${ }^{170} \mathrm{Also}$, the corporation, even today, may confer ostensible authority on any of its agents to bind the corporation effectively to outside parties. In fact, all of the normal agency rules have already been held to apply, so that there should be no doubt of the safety of outsiders contracting with any authorized agents of the corporation even though these agents are performing functions normally exercised by a board of directors.

Where the board of directors is retained, a simple provision, such as is found in the North Carolina statute, ${ }^{171}$ can expressly protect those dealing with the corporation who might not otherwise be aware of new limitations on the customarily plenary powers which the board might formerly have been reason-

168 Under the Model Act the number of directors may be fixed in the bylaws. ABA-ALI Moder Bus. CoRp. Act. $\$ 34$ (1953). The power to amend the bylaws, however, is given to the directors. $I d$. $\$ 25$.

${ }^{169}$ See 13 AMr. Jur. Corporations $\$ 997$ (1938); Ballantine 201-16.

${ }^{170}$ See Sherman v. Fitch, 98 Mass. 59 (1867). The agent's contract will also be held to bind the corporation despite his lack of authority where the corporation consciously accepts the benefits of the agreement. See Jourdan v. Long Island R.R., 115 N.Y. 360, 22 N.E. 153 (1889); Louisville, N.A. \& C. Ry. v. Carson, 151 Ill. 444, 38 N.E. 140 (1894); Carnahan v. Buck Co., 250 Mich. 198, 229 N.W. 513 (1940); Jacobson v. National Tea Co., 51 N.D. 889, 200 N.W. 910 (1924).

${ }^{171}$ See N.C. GEN STaT. \$§ 55-24(b), 55-73(c) (1960). 
ably presumed to possess. Full third-party protection should be achieved by statutory or case law acceptance of the British "indoor-management" rule 172 which protects all outsiders against secret limitations on corporate agents' authority.

Whatever the best rule might be, it is clear that outsiders dealing with a corporation, even though it abolishes or severely limits its board of directors, will be as well off as under the present law. The interest of the state, i.e., the interests of these two groups, is, therefore, fully consonant with leaving corporate management in the hands of those to whom the common law confided that power-the shareholders.

Modern legislation has tacitly permitted the shareholders to exercise this power by taking advantage of the labyrinthine ways of the law, and in a few instances has sought to directly reconfer the privilege which judicial interpretation took from them. It is time that this deviation from reason be corrected, and the powers of shareholders openly restored.

${ }^{172}$ See Stevens 774; Baker \& Cary, Cases and Materials on Corporations 126 (3d ed. 1959). 